NBER WORKING PAPER SERIES

\title{
A CURE WORSE THAN THE DISEASE? CURRENCY CRISES AND THE OUTPUT COSTS OF IMF-SUPPORTED STABILIZATION PROGRAMS
}

\author{
Michael M. Hutchison \\ Working Paper 8305 \\ http://www.nber.org/papers/w8305 \\ NATIONAL BUREAU OF ECONOMIC RESEARCH \\ 1050 Massachusetts Avenue \\ Cambridge, MA 02138 \\ May 2001
}

This paper was written for the NBER conference "Management of Currency Crises," March 29-31, 2001. Research Assistance from Ilan Neuberger is gratefully acknowledged. Hiro Ito, Kimberly Peterson and Sum-Yu Chiu helped with data collection. Timothy Lane and Patricia Gillett graciously helped in obtaining data on IMF programs. Comments from NBER conference participants, and especially the discussant, Gian Maria Milesi-Ferretti, are appreciated. Thanks also to brownbag workshop participants at UC Santa Cruz, especially Mike Dooley, Rob Fairlie and Donald Wittman. The views expressed herein are those of the author and not necessarily those of the National Bureau of Economic Research.

(C) 2001 by Michael M. Hutchison. All rights reserved. Short sections of text, not to exceed two paragraphs, may be quoted without explicit permission provided that full credit, including $\odot$ notice, is given to the source. 
A Cure Worse Than the Disease? Currency Crises and the Output Costs of

IMF-Supported Stabilization Programs

Michael M. Hutchison

NBER Working Paper No. 8305

May 2001

JEL No. E63, F34, F41, O19

\begin{abstract}
$\underline{\text { ABSTRACT }}$
This paper investigates the output effects of IMF-supported stabilization programs, especially those introduced at the time of a severe balance of payments/currency crisis. Using a panel data set over the 1975-97 period and covering 67 developing and emerging-market economies (with 461 IMF stabilization programs and 160 currency crises), we find that currency crises - even after controlling for macroeconomic developments, political and regional factors - significantly reduce output growth for 1-2 years. Output growth is also lower (0.7 percentage points annually) during IMF-stabilization programs, but it appears that growth generally slows prior to implementation of the program. Moreover, programs coinciding with recent balance of payments or currency crises do not appear to further damage short-run growth prospects. Countries participating in IMF programs significantly reduce domestic credit growth, but no effect is found on budget policy. Applying this model to the collapse of output in East Asia following the 1997 crisis, we find that the unexpected (forecast error) collapse of output in Malaysia-where an IMF-program was not followed-- was similar in magnitude to those countries adopting IMF programs (Indonesia, Korea, Philippines and Thailand).
\end{abstract}

Michael M. Hutchison

Department of Economics

Social Sciences 1

University of California, Santa Cruz

Santa Cruz, CA 95064

hutch@cats.ucsc.edu 


\section{Introduction}

There is considerable debate over the output and employments effects of IMFsupported stabilization programs. This controversy seems especially heated for countries facing acute balance of payments problems and currency crises, as witnessed in 1997 in Korea, Indonesia and Thailand and elsewhere. Stiglitz (2000), for example, supports critics of the IMF who argue “...the IMF's economic 'remedies' often make things worse-turning slowdowns into recessions and recessions into depressions." Some academic work also reaches this conclusion. Bordo and Schwartz (2000), for example, conclude, "...the recent spate of [IMF] rescues may be the case of the medicine doing more harm than good" (p. 60) ${ }^{1}$. Similar statements by other leading economists are commonplace.

Despite these strong statements about the value of recent IMF programs, no consensus has emerged about the impact of these programs on the real side of the economy ${ }^{2}$. Most empirical studies using panel data sets and regression techniques find that IMF-supported programs improve the balance of payments and current account (e.g. Khan, 1990; Conway, 1994; Bagci and Perraudin, 1997; Bordo and Schwartz, 2000).

This is not surprising since a key purpose of the IMF is "...to give confidence to members by making the Fund's resources temporarily available to them under adequate safeguards, thus providing them with the opportunity to correct maladjustments in their

\footnotetext{
${ }^{1}$ Part of the criticism against the IMF is that it contributes to moral hazard by creating the expectation of bailouts (implicit debt guarantees) whenever countries face balance of payments problems. Empirical evidence on this point is mixed. For example, Dreher and Vaubel (2001) find support for moral hazard associated with IMF programs, while Lane and Phillips (2000) do not. See Willett (2000) for a recent review and evaluation of the literature on the debate surrounding the role of the IMF.

${ }^{2}$ There is a large literature reviewing the effects of IMF-supported stabilization programs. See, for example, Beveridge and Kelly (1980), Bird (1996), Bordo and James (2000), Connors (1979), Convoy (2000), Edwards (1989), Gylafson (1987), Killick et al. (1992), Pastor (1987) and Santaella (1996). Bird,
} 
balance of payments without resorting to measures destructive of national or international prosperity" (IMF Articles of Agreement, Article I (v)).

Views on the ultimate output and employment effects of IMF programs, however, appear much more divergent than on the balance of payments effects. On the surface, it may seem odd that countries would choose to participate in an IMF stabilization program if it were not in their best interests to do so. That is, participation in a program would presumably be unlikely if the output costs were perceived to be particularly large, outweighing the benefits arising from improvement in the balance of payments, continued access to credit markets and so on. Stiglitz (2000) and others argue, however, that while officially the IMF doesn't force countries to participate in programs and negotiate conditions, "In practice, it undermines the democratic process by imposing policies."

A number of previous studies have attempted to measure the output costs of IMFprogram participation. However, these studies have reached radically different conclusions—-with results suggesting sizeable declines in output growth arising from participation in IMF programs (e.g. Przeworski and Vreeland, 2000) to quite strong positive output effects (e.g. Dicks-Mireaux et al., 2000). These conflicting results arise from several sources, including differences in the types of IMF programs that are investigated; differences in the groups of countries that are investigated (e.g. poor developing versus emerging market economies); differences in the methodologies that are employed; and, perhaps most important, how other factors influencing output growth are taken into account.

Hussain and Joyce (2000) investigate the factors that cause countries to repeatedly enter into IMF programs, and Joyce (2001) investigates the factors that determine the duration of IMF programs. 
One area that has not been sufficiently addressed in previous work is the role of severe currency and/or balance of payments crises on output growth and how these events interact with subsequent participation in IMF programs. We argue that Heckman's (1979) Inverse Mills Ratio (IMR) approach does not adequately control for selection bias in this case, since "participation equations" in this literature (predicting whether a country participates in an IMF program) generally have low explanatory power. This is partly because $2 / 3$ of IMF programs are not associated with severe balance of payments and/or currency crises (discussed in section 4). Our approach, by contrast, is to measure the output cost of participation in an IMF program, and investigate whether there are feedback effects that make implementation of programs especially problematic in the immediate aftermath or concurrent with an ongoing balance of payments/currency crisis. Our study focuses on three related questions: First, given that a country is already facing a severe currency crisis, does participation in an IMF-supported stabilization program tend to make real GDP growth weaker? Second, can one identify the channels (policy instruments) through which participation in IMF-supported programs affect real GDP? And, third, how much of the downturn in East Asia following the 1997-currency crisis may be attributed to participation in IMF programs?

To address the first question we control for the effect of a currency crisis on real GDP, and consider whether there is an additional effect arising from IMF-program participation at this time. We want to be sure that the effect of a currency crisis on GDP is not inadvertently attributed to participation in an IMF program. The second question asks whether we can identify the policy channel or policy mechanism through which IMF-program participation affects real GDP growth. Beyond providing countries with 
access to substantial lines of credit, IMF programs are generally associated with conditions on the future conduct of fiscal, credit and other policies. Identifying the way IMF conditionality affects the formulation of policy in practice (ex post)-- as opposed to the agreements themselves (ex ante)-- is an important step in determining how participation in programs might affect GDP. If the critics of the IMF are rightconditionality leads to overly restrictive macroeconomic policies and poor output performance - then it should show up in the data. Finally, the answer to the third question should shed light on the macroeconomic performance of East Asian countries that faced currency crises in 1997, distinguishing those that entered into IMF programs (Korea, Thailand, the Philippines and Indonesia) from the country that did not participate (Malaysia).

To investigate these issues we focus on short-run IMF stabilization programs (Stand By Agreements and Extended Fund Facilities) that are explicitly focused on balance of payments adjustment, rather than programs directed primarily toward structural reform and poverty reduction. The broadest spectrum of developing and emerging-market countries possible is considered where the key limitation on the number of countries is the availability of macroeconomic data. The estimation methodology employed to investigate real growth effects of IMF programs is the General Evaluation Estimator (GEE). In this context, we control for the occurrence of recent currency/balance of payments crises and also test for interaction effects between the two events. This allows us to answer the question: Is the adverse output effect of a currency crisis made worse when the IMF steps in with a stabilization package? We test the basic model using a panel data set with country-specific fixed effects. Simple reaction functions are also 
estimated to characterize the influence of IMF programs on the formulation of macroeconomic policy. We take into account the effect of recent currency crises on policy as well as the effects of self-selection bias.

Section 2 discusses the GEE methodology, and how we control for recent occurrences of currency crises. Section 3 discusses the data employed in the study and our selection of IMF programs to investigate. Section 4 provides a statistical background and summary statistics on the size, frequency over time, and regional distribution of IMF programs. We also consider the probability of a country adopting an IMF program conditional upon having had a recent currency crisis. Section 5 presents the primary empirical results of the study. This section presents estimation results of the "reduced form" output equation with explanatory variables that include balance of payments/currency crises and IMF program participation. It also applies the model to explaining the recessions faced by East Asian countries following the 1997 currency crisis. Section 6 presents results from estimating policy reaction functions, and the effect of IMF programs on credit policy. Section 7 concludes the paper.

\section{Section 2. GEE Methodology: Controlling for Currency and BOP Crises}

The basic General Evaluation Estimator (GEE) methodology employed in our study was first applied to the evaluation of IMF programs by Goldstein and Montiel (1986). It is based on the idea that one can derive a counterfactual—what would have happened to an IMF-participating country if it had not adopted a program—by investigating the policy responses of non-participating countries. The key element in this approach is that it must be possible to characterize macroeconomic policy choices by a 
simple and stable (over time and across countries) reaction function that holds for both participating and non-participating countries. We extend this standard model by introducing currency/balance of payments crisis as an additional factor influencing the evolution of output. We also introduce an interactive term that measures any additional adverse effect on output that is associated with IMF programs directly following a currency crisis.

The growth of real GDP for the $i$ th country at time $t\left(y_{i t}\right)$ is explained by policies that would have been observed in the absence of an IMF-supported program $\left(x_{i t}\right)$; exogenous external factors $\left(w_{i t}\right)$; the recent occurrence of a currency or balance-ofpayments crisis $\left(D_{i(t-1)}^{c c}\right)$; the existence of an IMF-supported program ( $D_{i t}^{i m f}$ ); and unobservable random disturbances $\left(\varepsilon_{i t}\right)$.

$$
y_{i t}=\beta_{o}+\beta_{k} x_{i t}+\alpha_{h} w_{i t}+\beta^{c c} D_{i(t-1)}^{c c}+\beta^{i m f} D_{i t}^{i m f}+\beta^{\mathrm{int}}\left(D_{i(t-1)}^{c c} * D_{i t}^{i m f}\right)+\varepsilon_{i t}
$$

where $x$ is a $k$-element vector of policy variables for country $i$ at time $t$ that would be observed in the absence of IMF support, $w$ is an $h$-element vector of exogenous variables for country $i$ at time $t, D_{i(t-1)}^{c c}$ is a dummy variable equal to unity if the country has recently experienced a currency crisis (and zero otherwise), $D_{i t}^{i m f}$ is a dummy variable equal to unity if a short-run IMF program is in effect (and zero otherwise), $D_{i t}^{i m f} * D_{i(t-1)}^{c c}$ is an interaction term measuring additional effects on output growth arising from a currency crisis that is immediately followed by an IMF program, and $\varepsilon_{i t}$ is a zero mean, 
fixed variance, serially uncorrelated, disturbance term ${ }^{B} \cdot \beta_{0}$ is a vector of country fixed effects (allowing average growth rates to vary across countries in the sample), $\beta_{k}$ is a $k$ element vector measuring the impact of policy changes on output, $\alpha_{h}$ is a $h$-element vector measuring the impact of exogenous factors on output, $\beta^{c c}$ measures the effect of currency/balance-of-payments crises on output growth, $\beta^{\text {imf }}$ measures the affect on output from participation in an IMF-supported stabilization program, and $\beta^{\text {int }}$ measures the effect of the interaction term.

After postulating a rule for the $k$-element vector of policies that would have taken place in the absence of an IMF-supported program $\left(x_{i t}\right)$, the model is estimated (with fixed effects) using panel data drawn from countries and periods in which IMF support was in place and those in which IMF support was absent. The aim is to get consistent estimates for $\beta^{\text {imf }}$ and $\beta^{\text {int }}$-- the effects of IMF-support on output.

Policies adopted in the absence of an IMF-supported program $\left(x_{i t}\right)$ are directly observable only for non-program periods, and a key part of the GEE estimation approach is therefore to construct a counterfactual for policies during programs. This counterfactual is based upon a policy reaction function that links changes in the policy instrument to the deviation of the observed lagged value for output growth from its desired value $\left(y_{i t}^{d}\right)$. The policy reaction function is described by:

$$
\Delta x_{i t}=\gamma\left[y_{i t}^{d}-y_{i(t-1)}\right]+\eta_{i t}
$$

\footnotetext{
${ }^{3}$ See Dooley (1999) and Gupta et al. (2000) for discussions of the factors that cause output to fall following a currency crisis.
} 
where $\eta_{i t}$ is a zero mean, fixed variance, serially uncorrelated error term assumed to be uncorrelated with $\varepsilon_{i t}$ and $\Delta$ is the difference operator. The parameter $\gamma$ indicates the extent to which the policy instrument is adjusted in response to disequilbria in the target variable. Substituting (2) into (1) and subsuming desired output growth into the vector of fixed-effect constant terms for each country ( $\left.\beta_{0}^{\prime}\right)$ gives:

$$
\begin{aligned}
& \Delta y_{i t}=\beta_{o}^{\prime}-\left(\beta_{k} \gamma_{k}+1\right) y_{i(t-1)}+\beta_{k} x_{i(t-1)}+\alpha_{h} w_{i t}+\beta^{c c} D_{i(t-1)}^{c c}+\beta^{i m f} D_{i t}^{i m f} \\
& +\beta^{\text {int }}\left(D_{i(t-1)}^{c c} * D_{i t}^{i m f}\right)+\left(\varepsilon_{i t}+\beta_{k} \eta_{i t}\right)
\end{aligned}
$$

Equation (3) is the basic GEE reduced form model as applied in earlier studies (Dicks-Mireaux et al., 2000; Goldstein and Montiel, 1986; and others). The usefulness of the model, as discussed in detail in Dicks-Mireaux et al. (2000), depends on (i) whether individual country behavior may be aggregated in a stable (across countries and time) uniform model; (ii) whether it may be assumed that the policy reaction function of a program country, had it not received IMF support, is identical to that of non-program countries that did not seek support; and (iii) whether the additive term $\beta^{\text {imf }} D_{i t}^{\text {inf }}$ and the interactive term $\beta^{\text {int }}\left(D_{i t}^{i m f} * D_{i t}^{c c}\right)$ can fully capture all the channels (static and dynamic) through which participation in IMF-programs may affect output growth.

Unlike previous studies, we control for the (lagged) occurrence of currency and balance of payments crises as a predetermined variable in the output growth equation. We also take into account the possibility that an interactive effect (operating between currency crises and the adoption of IMF programs) may have an additional impact on output growth. Leaving out these terms could leave the output growth equation misspecified and lead to biased estimates. 
Section 3. Selection of IMF Programs and Data Description

\section{Selection of IMF Programs}

The main IMF facilities designed to meet short-run balance of payments stabilization are Standby Arrangements (SBA) and the enhanced fund facility (EFF). In general, Fund members can access credit tranches from the General Resources Account (GRA) either by means of IMF program arrangements or by means of "outright purchases." Outright purchases are limited, typically, for the first $25 \%$ of the member's quota and do not involve any phasing or conditionality. Stand-by arrangements have been the main instrument through which members gain access to further credit tranches. ${ }^{\mathrm{E}} \mathrm{Stand}$ By Arrangements (SBA) typically last for $12-18$ months (the legal maximum is 3 years) and first tranche drawings do not require strict conditionality. Any drawings beyond the first tranche require both phasing out and stricter conditionality and are limited to $100 \%$ of quota annually (300\% cumulatively together with the Extended Fund Facility, EFF, as discussed below). Repurchase obligations last about $31 \frac{1}{4}-5$ years from the date of purchase.

The Extended Fund Facility, established in 1974, provides somewhat longer-term financing to countries in need of structural economic reforms. EFF arrangements typically last for 3 years; phasing and conditionality are similar to the SBAs with an emphasis on longer-term structural reforms. Quota limits are identical to the SBAs while repurchases last much longer ( $4 \frac{1}{2}-10$ years). Both facilities are subject to the same rate

\footnotetext{
${ }^{4}$ This discussion is based on International Monetary Fund (2000). Review of Fund Facilities-Preliminary Considerations (IMF, Washington D.C).
} 
of interest for repayments. ${ }^{6}$ The Supplemental Reserve Facility (SRF), introduced in 1997 in the Korean stabilization program, aims to supplement resources made available under SBAs and the EFF in order to provide financial assistance for exceptional balance of payments difficulties. Penalty interest rates (increasing over time) and short repayment periods (1-11/2 years) insure that these are taken only in exceptional circumstances. We use the SBA and EFF programs (and, for Korea in 1997, the new SRF program) as our definition of "IMF-supported stabilization programs." These are the only programs clearly linked to short-term balance of payments adjustment. (There are no cases of SBA and EFF programs being approved in the same year in this data sample). By contrast with these programs, some Fund facilities are designed with other objectives in mind. We do not include these programs since their primary objective is not short-run balance-of-payments stabilization and adjustment.

For example, separate from the General Resources Account, the Fund established the Structural Adjustment Facility (SAF) in 1986 for "all low-income countries ...that are in need of such resources and face protracted balance of payments problems" [italics mine] ${ }^{8}$, and its successor, the Enhanced Structural Adjustment Facility (ESAF), in 1987. In 1999, the ESAF was replaced by the Poverty Reduction and Growth Facility (PRGF). These are managed separately by the IMF and are financed from the sale of IMF-owned gold together with resources provided by members in the form of loans or grants to the Fund, as Trustee, for the purpose of helping low-income member countries. These

\footnotetext{
${ }^{5}$ As the Articles of Agreement state, they were defined as "a decision by the Fund by which a member is assured that it will be able to make purchases from the General Resources Account in accordance with the terms of the decision during a specified period and up to a specified amount" (Article XXX (b)).

${ }_{7}^{6}$ Starting in 1989, the rate of charge was linked directly to the SDR interest rate, and adjusted weekly.

${ }^{7}$ In our sample, the only such case is the agreement with Korea in 1997.

${ }^{8}$ As determined by the International Development Association (IDA), the World Bank's concessional window (the current cutoff point for IDA eligibility is a 1999 per capita GDP level of \$885).
} 
resources are used to finance highly concessional, low-interest loans. Eligible countries can withdraw up to $185 \%$ of their quota conditional on their balance of payment needs and the strength of their adjustment program. The interest rate charged is $0.5 \%$; and repayments are over a 10 year period.

By contrast with our study, Dicks-Mireaux et al. (2000) focus on the structural adjustment programs in their research (SAF and ESAF) and measure the effects of these IMF-supported programs on poor developing economies. Bordo and Schwartz (2000), on the other hand, consider both IMF stabilization and structural adjustment programs, and use a mixed sample of 20 emerging market and developed countries (including Australia and New Zealand). Similarly, Przeworski and Vreeland (2000) do not differentiate between programs, including both stabilization and structural adjustment IMF programs. But, similar to our work (and unlike Bordo and Schwartz (2000) or Dicks-Mireaux et al. (2000)), they consider a broad set of developing countries. Our basic results, however, are robust to broadening the definition of IMF programs to include the SAF and ESAF.

\section{Defining Currency and Balance of Payments Crises}

Our indicator of currency and balance of payments crises is constructed from "large" changes in an index of currency pressure, defined as a weighted average of monthly real

exchange rate changes and monthly (percent) reserve losses. ${ }^{2}$ Following convention (e.g. Kaminsky and Reinhart, 1999) the weights are inversely related to the variance of changes of each component over the sample for each country. Our measure, taken from

\footnotetext{
${ }^{9}$ Our currency pressure measure of crises does not include episodes of defense involving sharp rises in interest rates. Data for market-determined interest rates are not available for much of the sample period in many of the developing countries in our dataset.
} 
Glick and Hutchison (2000 and 2001), presumes that any nominal currency changes associated with exchange rate pressure should affect the purchasing power of the domestic currency, i.e. result in a change in the real exchange rate (at least in the short run). This condition excludes some large depreciations that occur during high inflation episodes, but it avoids screening out sizeable depreciation events in more moderate inflation periods for countries that have occasionally experienced periods of hyperinflation and extreme devaluation. ${ }^{10}$ An episode of severe exchange rate pressure is defined as a value in the index-a threshold point-- that exceeds the mean plus 2 times the country-specific standard deviation, provided that it also exceeds 5 percent. 1.1 The first condition insures that any large (real) depreciation is counted as a currency crisis, while the second condition attempts to screen out changes that are insufficiently large in an economic sense relative to the country-specific monthly change of the exchange rate.

For each country-year in our sample, we construct binary measures of currency crises, as defined above ( $1=$ crisis, $0=$ no crisis $)$. A currency crisis is deemed to have occurred for a given year if the currency pressure index for any month of that year satisfies our criteria (i.e. two standard deviations above the mean as well as greater than five percent in magnitude). To reduce the chances of capturing the continuation of the same currency crisis episode, we impose windows on our data. In particular, after identifying each

\footnotetext{
${ }^{10}$ This approach differs from that of Kaminsky and Reinhart (1999), for example, who deal with episodes of hyperinflation by separating the nominal exchange rate depreciation observations for each country according to whether or not inflation in the previous 6 months was greater than 150 percent, and they calculate for each sub-sample separate standard deviation and mean estimates with which to define exchange rate crisis episodes.

${ }^{11}$ Other studies defining the threshold of large changes in terms of country-specific moments include Kaminsky and Reinhart (1999); Kaminsky, Lizondo, and Reinhart (1998); and Esquivel amd Larrain (1998). Kaminsky and Reinhart (1999) use a three standard deviation cut-off. While the choice of cut-off point is somewhat arbitrary, Frankel and Rose (1996) suggest that the results are not very sensitive to the precise cut-off chosen in selecting crisis episodes.
} 
"large" indication of currency pressure, we treat any similar threshold point reached in the following 24-month window as a part of the same currency episode and skip the years of that change before continuing the identification of new crises. With this methodology, we identify 160 currency crises over the 1975-97 period.

\section{Other Variables in the Output Growth Equation and Policy Function}

Estimation of the reduced from equation (3) for the output growth equation necessitates that the external exogenous variables influencing output growth (vector $\omega_{i t}$ ) and the (lagged) policy instruments (vector $x_{i(t-1)}$ ) are identified. The external exogenous factors included are (trade-weighted) lagged external growth rates of major trading partners and the lagged rate of real exchange rate overvaluation. ${ }^{12}$ The (lagged) policy factors considered are the change in the budget surplus to GDP ratio, inflation, and credit growth.

In the policy reaction function estimates of equation (2), we also consider regional dummy variables and a measure of policy "autocracy." 13 In controlling for sample selection bias, a probit equation explaining the likelihood of IMF-program participation is estimated. Other variables employed in this estimation, not noted above, are the (lagged) foreign exchange reserves to imports ratio, the change in the current account to GDP ratio, and real per capita GDP growth. These macroeconomic data series are taken from the International Monetary Fund's IFS CD-ROM.

\footnotetext{
${ }^{12}$ Real exchange rate overvaluation is defined as deviations from a fitted trend in the real trade weighted exchange rate. The real trade-weighted exchange rate is the trade-weighted sum of the bilateral real exchange rates (defined in terms of CPI indices) against the U.S. dollar, the German mark, and the Japanese yen. The trade-weights are based on the average bilateral trade with the United States, the European Union, and Japan in 1980 and 1990.
} 
The minimum data requirements to be included in our study are that GDP are available for a minimum of 10 consecutive years over the period 1975-97. This requirement results in a sample of 67 developing countries. ${ }^{14}$ We use annual observations in our analysis. While we employ monthly data for our (real) exchange rate pressure index to identify currency crises and date each by the year in which it occurs, using annual data enables inclusion of a relatively large number of countries. The appendix table provides details on the countries included in the sample, the currency crisis dates, and the periods when countries participated in IMF programs.

\section{Section 4. Summary Statistics: IMF Programs, Currency Crises and the Economy IMF Programs: Size, Growth and Regional Distribution}

The frequencies of the IMF programs are shown in Table 1 (for all countries) over the 1970-99 period. (Descriptive statistics on IMF programs reported in Tables 1-2 cover the 1970-99 period, while the other tables involving statistical analysis cover the 1975-97 period.) The total number of programs, the average size in terms of SDRs (in parentheses), and the size of the average program as a percent of the recipient country GDP (in brackets) is given in the table. The table is divided into short-term stabilization (focus of our study) and longer-term structural adjustment programs, and also separated into five-year intervals.

Over the 30-year period, $845 \mathrm{IMF}$ programs were approved, of which 678 were short-run stabilization programs—-Standby Agreements (SBA) or the Extended Fund Facility (EFF). Only 167 were longer-term structural adjustment programs-Structural

\footnotetext{
${ }^{13}$ Autocracy is an index ranging from 1 to 10 , with 10 indicating the most "closed" political system. This source of this variable is the "polity" database.
} 
Adjustment Facility (SAF), Enhanced Structural Adjustment Facility (ESAF) or the Poverty Reduction and Growth Facility (PRGF).

The number of programs reached a peak in the early 1980s (with the Mexican debt crisis and debt problems in other Latin American countries), both in terms of number of programs (169) and size relative to the economies involved (average program size over 4 percent of GDP). The number of IMF programs is not growing, nor is the size relative to the economies involved (about 2 percent of GDP in 1995-99). The size of the average program in terms of SDRs jumped in the late 1990s, however, due to the large economic size of the countries going to the IMF for assistance (e.g. Brazil, Indonesia, Mexico, Russian Federation, and South Korea). ${ }^{.15}$

The regional breakdown of program approvals is given in Table 2. The short-term stabilization programs (SBA and EFF) are primarily directed to Latin America and Africa, with about 30 and 35 percent respectively of program approvals. Africa dominates the long-term structural programs (SAF/ESAF and PRGF) with 70 percent of the programs over the period.

\section{Currency Crises and IMF Program Participation}

An important part of our study is to investigate the link between currency crises, real output developments and IMF stabilization programs. Table 3 shows the relative frequencies of currency crises and IMF stabilization program participation for the 67 countries in our sample over the 1975-1997 period. Panel A shows the contemporaneous frequencies (and associated chi-squared independence tests), i.e. contemporaneous

\footnotetext{
${ }^{14}$ The developing country sample excludes major oil-exporting countries.

${ }^{15}$ This includes the disbursement to Korea under the Supplemental Reserve Facility (SRF).
} 
currency crises and contemporaneous IMF program participation. Statistical independence of these observations is rejected at the 99 percent level of confidence, but only 18 percent of IMF program participation observations are associated with currency crises. However, a substantially higher percentage ( 28 percent) of the currency crisis observations coincide with IMF program observations.

Panel B shows the link between IMF programs and contemporaneous and lagged currency crises. This shows a stronger link than the contemporaneous relationship. Statistical independence is again rejected (at greater than 1 percent significance). 33 percent of contemporaneous IMF program participation observations are associated with either a contemporaneous or previous (one-year lag) currency crisis. Similarly, 28 percent of contemporaneous or lagged currency crises are associated with a contemporaneous IMF program. Hence, almost a third of currency crisis observations are linked to an IMF program within the current year or next year. Of course, this implies that about $2 / 3$ of the currency crisis observations are not linked with IMF program participation.

\section{Macro Developments: Participation/Non-participation and Before/After Statistics}

Tables 4-6 present summary statistics on the timing of IMF programs (SBA and EFF) participation and key macroeconomic developments. Table 4 shows sample mean values for macroeconomic developments during program years and non-program years. The first two columns report the statistics for all countries (both for those countries that at some point participated in IMF programs and for those that did not), focusing on non-program observations and IMF-program observations. Real GDP growth was about 4\% [1082 observations] during the non-program years and $2.9 \%$ during the program years [585 
observations]. This difference is significantly different at the 99 percent level of confidence (t-statistic equal to 4.83). Inflation and budget deficits are significantly higher during the program years, but no substantive difference between program and nonprogram years is detected in the growth rate of credit or the current account balance.

There may be systematic differences in the types of countries that approach the IMF for assistance, however. Focusing only on countries participating in IMF programs (second, third and fourth columns) avoids this selection bias. For countries involved in IMF programs (at some point during the sample), average GDP growth was 3.6\% during non-program years and $2.9 \%$ during program years. This difference is statistically significant. Inflation was also significantly lower during the non-program years. No difference is discernible in credit growth or the budget and current account balances.

If one simply compares IMF-program countries (both during program and nonprogram years) with those not having a program during the sample period, the differences are substantial-- but not surprising. Countries that have never participated in an IMF program during our sample period-- presumably not having had a need to participate-exhibit much stronger economic fundamentals: much higher GDP growth rates $(6.8 \%$ versus 3.4\%), lower inflation, lower credit growth, and balanced positions in the current account and budget.

Table 5 focuses on the before/after time series of countries participating in IMF programs. Four-year windows are imposed. The table shows that output growth does not decline substantially when a country enters an IMF program, but does increase significantly during the two-year period following the program. Credit growth, by contrast, falls significantly during the IMF program and stays at the lower rate of growth 
following the program. No statistically significant shifts are noted in the time pattern of inflation, the current account balance or the budget surplus.

Table 6 undertakes the same decomposition as Table 5 but instead imposes only a two-year window, together with a one-year interval before and after IMF program participation. Real GDP growth is not much different one year before and during an IMF program, but rebounds substantially the year following a program. Inflation drops before/during and after programs, but the variation in the sample is so great that the differences are not statistically significant. Credit growth drops sharply following an IMF program and stays lower one year following a program. The budget balance improves during an IMF program and stays at a lower level following the program.

Tables 5 and 6 clearly demonstrate that economies typically experience slow growth prior to entering into an IMF program, and sluggish growth continues until the program is concluded. It does not appear that participation in the IMF program directly contributed to slower growth. Inflation and credit growth both declined during the IMF-program and stayed lower than the pre-program period. In short, these summary statistics paint a classic recession-rebound pattern but it is not clear if IMF program participation played a role.

\section{Section 5. Real Output Effects of IMF Programs}

\section{General Evaluation Estimator (GEE) Estimates}

The reduced form GEE estimates (equation 3) are reported in Table 7. White's consistent standard errors are reported. The first column reports the model without controlling for country fixed effects or currency crises. The lagged control variables are 
the change in the budget surplus ratio, inflation, credit growth, external (world) output growth, and real exchange rate overvaluation. A lagged dependent variable, as suggested in the theoretical formulation of the model, is also included. The focus is the coefficient on the IMF-program dummy. The coefficient estimate is statistically significant (99 percent level of confidence) and indicates that real GDP growth is lowered by about 1 percent during each year of IMF-program participation.

The estimated coefficients on lagged external growth (positive) and lagged real exchange rate overvaluation (negative) have the predicted signs and are statistically significant. In terms of the policy variables, the estimated coefficient on the lagged change in the budget surplus is positive and the estimated coefficient on lagged credit growth is negative. Both are statistically significant. Interpreting these coefficients in terms of reaction functions, the rise in the lagged budget surplus (rise in credit growth) could lead to a more expansionary (restrictive) contemporaneous fiscal policy (credit policy) and hence rise (fall) in output growth. Other interpretations are possible. For example, countries with more sustainable fiscal policies and lower credit growth may have systemically higher real output growth rates. Inclusion of fiscal and credit variables may be picking up important cross-country differences in economic performance.

Column 2 reports results for the model with country fixed effects (dummy variables for each country to capture the significant differences in growth rates over the full sample period) and the currency crisis variable. These variables are highly statistically significant, increasing the overall explanatory power of the model (R-squared) from 12 percent to 21 percent. A currency crisis in year $\mathrm{t}-1$ is associated with a decline in output growth in year $t$ of about 1.5 percentage points. The coefficient estimate on the IMF- 
participation variable decreases substantially when the currency crisis variable is taken into account, indicating that output growth is about 0.74 percentage points less annually for each year of IMF-program participation. This coefficient estimate, however, is only significant at the 90 percent level of confidence.

Column 3 reports the results of the model when both contemporaneous and lagged currency crisis variables are included in the regression. Both of the currency crisis variables are negative and statistically significant. The coefficient estimate on the IMFprogram participation is similar (0.78) to the result reported in column 2.

Column 4 reports the results where the model includes an interactive term measuring the occurrence of an IMF-program that takes place around the time of a recent occurrence of a currency crisis (i.e. contemporaneous or in the previous year). The model estimates again suggest that a currency crisis leads to an output loss, but the coefficient estimate ($0.66)$ on the IMF program dummy variable is not statistically significant. Is the output loss associated with a currency crisis magnified if an IMF program is approved in the same year or immediately following a severe balance of payments or currency crisis? The interaction term in column 4 is not statistically significant, indicating that the output loss associated with a crisis does not appear to be affected by a country's participation in an IMF program.

Column 5 reports results from estimating a more dynamic specification of the model. The objective is to investigate whether the adverse effects from participating in an IMF program dissipate, or perhaps intensify, over time. This is accomplished by including three lags of the IMF-participation variable. It appears that the adverse output effects are felt during the years of IMF program participation (generally 1-3 years), but no 
significant additional effects are observed in subsequent years. That is, neither the sum of the coefficients on the three lagged values of program participation nor the joint test is statistically different from zero (see footnote $b$ to table 7).

In sum, the results are robust and indicate that participating in an IMF-program, regardless of whether a currency or balance of payments crisis has recently occurred, “costs" about 0.6-0.8 percentage points of real GDP growth annually. Our estimates are about half the size of the negative impact reported by Przeworski and Vreeland (2000) or Bordo and Schwartz (2000) $\frac{17}{17}$ and similar in magnitude to Conway (1994). Unlike Conway (1994), however, we do not find that the reduction in growth is followed by higher future output growth $\frac{18}{18}$.

It is noteworthy that we also tested for sample selection bias in the estimation procedure, and the results were unaffected. The estimates on the IMF and currency crisis variables did not change and the coefficient on IMR was not statistically significant. (The probit equation estimated to measure self-selection bias is presented in Appendix Table 3.) Of course, insignificance of the IMR variable may either be because selection bias is not an important issue or because the participation equation is misspecified. These results are not reported for brevity but are available from the author upon request. This finding is

\footnotetext{
${ }^{16}$ Przeworski and Vreeland (2000) estimate a long run growth model (using capital and labor growth as independent variables), dividing the sample into (IMF) program observations and non-program observations. They also include the IMR in the regression. Their conclusions regarding the growth effects of IMF-program participation are based on the difference between the estimated constant terms in the two regressions.

${ }^{17}$ Bordo and Schwartz (2000) report a contemporaneous effect of IMF programs of $-1.61(t=-0.97)$ and a one-year lagged effect of $2.24(\mathrm{t}=2.67)$. The contemporaneous effect is insignificantly different from zero and the one-year lagged effect is significant at the 99 percent level of confidence. On balance, their results indicate that IMF program participation has a net positive effect on growth. Surprisingly, they conclude that: "The main detriment [of IMF program participation] is a temporary reduction in real growth." (p. 57) and "...the impression given by the annual data - that turning to the IMF may be harmful to a country's real economic performance..." (p. 60). Our results are not directly comparable, however, since they have a limited sample of emerging market and developed countries (20 total), and include short-run stabilization programs, structural adjustment, and poverty reduction programs in their study.
} 
similar to Dicks-Mireaux et al. (2000). (We do find IMR significant in the policy reaction functions, however.)

\section{Extensions: IMF Program Dating and Downturns Prior to IMF Program Approvals}

Table 8 presents several extensions of the basic output growth model. The first two columns use the conventional dating scheme employed in Table 7, i.e. dating the IMF program in the calendar year in which it was approved. The first column adds a oneyear leading indicator of IMF program participation ("lead IMF program participation dummy, $t+1$ ") and the second column adds a one-year leading indicator of IMF program approval (only the year of approval; subsequent program years are coded as zero). The descriptive evidence presented in Table 6 suggests that a downturn in output tends to lead (by one year) participation in an IMF program. A lagged dependent variable included in the basic output growth equation helps to account for this dynamic. If "cycles" are irregular, however, inclusion of the IMF leading variable might be able to better capture downward shifts in output growth occurring with some regularity prior to IMF program participation. The leading IMF dummy variable is not significant in either column 1 or 2 , however, and the contemporaneous effects are quite similar to those reported in Table 7.

The second two columns use an alternative-dating scheme for the implementation of IMF programs that has been used by Dicks Mireaux et al. (2000) and others. This dating scheme dates the IMF program to be in effect in year $t$ if it was approved in the first half of year $t$ or in the second half of year $t$-1. Again the leading IMF program dummy variable is not statistically significant. However, the estimated contemporaneous effects of IMF programs on output growth using the alternative-dating scheme do change

\footnotetext{
${ }^{18}$ Similar to our study, Conway (1994) uses only SBA and EFF programs in his study.
} 
somewhat. In particular, the estimated negative effect of an IMF program in column 3 (IMF program participation) rises to -1.22 and is significant at the 95 percent level of confidence. By contrast, the estimated output effect in the year of an IMF program approval is insignificant. These results indicate that changes in the dating scheme of IMF program implementation and program definition (whether defined as all years of participation or only the first year of approval) affect the results to some extent but do not change the basic findings.

We also estimated the basic model over the 1990-97 period, as the evolving nature of IMF programs and conditionality may have changed their effect on output. In particular, the number of conditions attached to IMF programs have increased in the 1990s. The coefficient on the IMF dummy drops to only -0.36 in this regression and is not significant at conventional levels.

\section{The East Asian Financial Crisis and Output Contraction}

Figure 1 presents the predicted values for output growth for the five East Asian countries that experienced a severe currency and balance of payments crisis in 1997. These predictions are for 1998 and based on 1997 values of the explanatory variables and the coefficient estimates_-including country-specific fixed effects—are based on the model presented in column 3 of Table 7 (estimates are based on 1975-97 data). The explanatory factors leading to the 1998 predicted value are decomposed into: (a) domestic factors (change in budget surplus, inflation, and credit growth), (b) external factors (external growth and real exchange rate overvaluation), (c) other factors (previous 
year's output growth and country-specific fixed effect), (d) the currency crisis effect, and (e) the IMF-participation effect.

Predicted output growth for all 5 countries is positive in 1998, and the forecast error (unexpected declines in output) is therefore very large. The negative effect exerted by the currency crisis and subsequent participation in an IMF program is entirely dominated by positive "other factors"- mainly a history of very strong growth in the region and the consequently large country-specific fixed effect growth factor-- and a modestly supportive external growth environment. The effect of the currency crisis was expected to slow output growth by between 1-2 percentage points and IMF-program participation (for Indonesia, Thailand, Korea and the Philippines) lowers predicted growth by about 0.8 percentage points.

The largest unexpected fall in real GDP was Indonesia (17.6 percentage points) and the least in the Philippines ( 3 percentage points). The average of the four negative forecast error for the four countries participating in IMF programs was 12.3 percentage points, not much different than the 13.5 unexpected fall in Malaysia's GDP. Not participating in the IMF program did not appear to help Malaysia avoid a huge fall in output, and this decline was similar to others in the region. 19 The 0.8 predicted negative effect of participating in an IMF program pales by comparison with the actual declines in output observed.

\footnotetext{
${ }^{19}$ Kaplan and Rodrik (2001) argue that, following the crisis, the imposition of capital controls in Malaysia, as opposed to adoption of an IMF program, led to a faster recovery and lower unemployment compared to Thailand and South Korea. They compare the aftermath of the imposition of controls in 1998 with the adoption of IMF programs in 1997 by Korea and Thailand (using the time-shifted difference-in-difference specification). However, this approach does not take into account a counterfactual that the Malaysian currency crisis probably would not have extended to September 1998 if it had adopted an IMF program in 1997.
} 
There appears to have been a common shock or common vulnerability in these countries-- not related to the IMF and unobserved in this model-- causing the unexpectedly large collapse in output. $\frac{20}{2}$ All of these countries serious banking problems that were associated with currency crises, a characteristic likely to cause substantially greater output effects, working through the disruption of credit and other channels (Glick and Hutchison, 2001). Taiwan, Hong Kong and Singapore avoided the worst of the currency and banking problems because they did not have significant external (foreigncurrency denominated) short term debt positions. Other factors, such as an abrupt loss of confidence after two decades of rapid growth and unrealistically high expectations for the region, may also have played a role.

\section{Section 6. Is Policy Changed by IMF Program Participation?}

An important assumption underlying the GEE strategy is that it is possible to characterize policy actions in the form of stable and systematic reaction functions (equation 2). This may prove extremely difficult since we are attempting to identify common responses from a broad spectrum of developing and emerging-market countries over a thirty-year period. The work of Dicks-Mireaux et al. (2000) highlight the problems in identifying a consistent policy reaction function even among low-income developing economies. For example, they do not find any significant determinants of the fiscal balance or net domestic credit. They conclude “...these estimates provide a weak basis for deriving estimates of the unobservable counterfactuals." (p. 508).

\footnotetext{
${ }^{20}$ It is possible that the "common shock" was indeed especially severe austerity programs associated with the IMF programs, and perhaps mimicked by Malaysia to gain international acceptance of its policies. However, the evidence reported by Kaplan and Rodrik (2001) and others, and the imposition of capital controls by Malaysia, does not support this view.
} 
Table 9 presents our estimates of policy reaction functions for domestic credit growth—a primary policy instrument for many developing economies. Domestic credit growth is also a key indicator of monetary policy used by the IMF in conditionality and surveillance. Equations for narrow money growth, broad money growth, and government budget policy-reaction functions were also estimated but the results are much weaker and not reported for brevity.

Column 1 reports the results of the basic policy reaction-function model for all observations in the sample (program and non-program years), while columns 2 and 3 report the estimates over the program and non-program observations, respectively. Consistent with the theoretical formulation of the model, the macroeconomic determinants consist of lagged values of the current account surplus (relative to GDP), inflation, real GDP growth, and whether or not the country experienced a currency crisis. Also included are regional dummy variables and a dummy variable for the form of government ("autocracy"). Further, in the equations for non-program years and program years we have included the Inverse Mills Ratio (IMR) to control for sample selection bias. (The probit model estimated with IMF program approvals as the dependent variable is reported in Appendix Table 3. The IMR is calculated from the predicted values of this model.)

The only significant macroeconomic predictors of credit growth, shown in columns (1)-(3), are lagged inflation and the occurrence of a currency crisis in the previous year. The coefficient estimates of lagged inflation range between 0.6-0.7, indicating that a one-percentage point rise in inflation is associated with a rise (fall) in nominal credit growth (real credit growth) of about $0.7(0.3)$ percentage points. 
Interpreting this equation as a reaction function suggests that, in response to a rise in inflation, the authorities respond by reducing real credit growth. The coefficient on the (lagged) currency crisis variable is positive and significant in columns 1 and 3, indicating that countries generally respond to currency crises by expanding credit growth.

The constant term is much lower during IMF programs (6.9) relative to the nonprogram observations (28.8), suggesting more restrictive policy on average during the IMF-program years. The IMR is significant in the IMF-program-years regression (column 3), indicating that sample selection bias is an issue-countries don't randomly enter into IMF programs and their decision to participate is systematically linked to domestic credit growth.

The regressions reported in columns 4 and 5 cover all years and control for IMFprogram participation by including a dummy variable in the regression. Country specific dummy variables are included in these regressions-- a fixed-effects model formulation-in order to control for the wide variation in average credit growth across countries. These results indicate the importance of controlling for country fixed effects in attempting to explain credit growth over such a wide diversity of countries. The impact of inflation is substantially reduced (to 0.4 ), indicating that inflation reduces real credit growth. The dummy variable on autocracy is also significant in one formulation of the model as are the regional dummy variables.

We find that, in column 4, IMF programs reduce domestic credit growth by about 4 percentage points during the period they are in effect. Inclusion of the interactive term, in column 5, indicates that currency crises tend to induce greater credit expansion (by 11 percentage points) and the joint coincidence of a recent currency crisis and current IMF 
program is associated with a contraction of credit by about 15 percent annually. The joint effect of a currency crisis (lagged) followed by an IMF program is estimated to reduce credit growth by about 5.6 percentage points (11.2-1.3-15.6).

These results suggest that IMF program participation is associated with restrictive credit growth. Investigations of budget policy and money growth, however, did not indicate any link between IMF program participation and policy. Even the credit reaction function is fairly weak, however, likely reflecting shifts in policy over time and the fact that the types of countries going to the IMF for assistance have very different characteristics than countries not going to the IMF.

\section{The East Asian Financial Crisis and Credit Growth}

The empirical credit growth equation (column 4 of Table 9) is employed to predict credit growth for the five East Asian countries that experienced currency crises in 1997. Predicted credit growth was divided into component parts and the "unexpected" (forecast error) calculated. In every case, credit growth in 1998 is predicted to be quite strong, ranging from 15.5 (Philippines) to 24.4 (Indonesia). Participation in IMF programs lowered predicted credit growth by about 4 percentage points, and the predicted response to the currency crises increased predicted credit growth by about 4 percentage points. 21

A sharp and unanticipated contraction (negative forecast error) was experienced in every country except for Indonesia following the East Asian currency crisis. The countries that participated in IMF programs experienced smaller unexpected declines (Korea: -8.4 percent; Philippines: -17.5 percent; Thailand: -18.2 percent) than did 
Malaysia (-23.2), and Indonesia experienced a sharp unpredicted jump in credit. The observed decline, as opposed to the negative forecast error, in credit growth was also largest in Malaysia at -2.7 percent. Indonesia, by contrast, experienced a 18.6 percent unpredicted rise in credit and an observed rise of 43 percent. Similar to the output growth prediction results, Malaysia was hurt at least as much by the Asian currency crisis as the IMF-program countries.

\section{Section 7. Conclusion}

The estimated cost of an IMF stabilization program, in terms of foregone output growth, is about $0.6-0.8$ percentage points during each year of program participation. Currency crises also reduce output growth over a two-year period by about 2 percentage points. Participation in an IMF-supported program following a balance of payments or currency crisis, however, does not appear to mitigate or exacerbate the output loss. This is despite the fact that countries participating in IMF-programs seem to follow much tighter credit policy when facing a severe balance of payments crisis. Moreover, there is some evidence that the decline in GDP growth generally precedes the approval of an IMF program and may not be attributable to program participation per se. These results are robust to estimation technique, model specification, types of IMF programs included, and corrections for sample selection bias.

The huge declines in output and credit growth in the wake of the 1997 Asian currency crisis were much larger than predicted by historical patterns linking GDP developments to currency crises, IMF program participation, external conditions and policy developments. Indeed, the models predicted fairly robust output growth and credit

\footnotetext{
${ }^{21}$ These results are not reported for brevity but are available from the author upon request.
} 
growth in 1998 despite the currency crises and, in most cases, participation in IMFsupported programs. The unexpected falls in output and credit were also very large in Malaysia, even though it chose not to participate in an IMF stabilization program at the time. Whether or not a country decided to participate in an IMF-supported program at the time of the Asian currency crisis seems to have had little affect on the ultimate output cost.

The effect of IMF-supported stabilization programs on output growth-- judging by the experiences of 67 countries with over 450 programs — does not appear large in comparison with the average growth rates of developing and emerging-market economies over the 1975-97 period. Nonetheless, whether or not the cost of participating in an IMFsupported stabilization program exceeds the benefit measured in terms of balance of payments adjustment and continued access to credit markets is an open question to be answered by policymakers in the countries involved. 


\section{Appendix: Participation in IMF-Supported Stabilization Programs}

Appendix Table 3 presents a probit equation attempting to explain participation in short-term IMF programs by a variety of economic determinants. Our selection of economic determinants is guided by previous literature in this area, especially Knight and Santaella (1997) who test a number of supply side (e.g. willingness of the IMF to approve programs) and demand side (e.g. demand of a particular country for IMF credits) determinants. This literature demonstrates that entering into an IMF agreement is not random, but guided by “... a clear set of observable economic factors that are strongly correlated with the event of approval of a financial arrangement." (p. 431). They find that a low level of international reserves, low per capita GDP, high ratio of external debt service (to export earnings), movements in the real exchange rate, weak GDP growth and a low rate of domestic investment induce countries to seek an IMF-supported program. Policy measures to enhance fiscal revenues, reduce government expenditures, to tighten domestic credit, and to adjust the exchange rate are significant factors likely to win IMF approval of programs.

We report similar results in Appendix Table 3. We find that an improvement in the budget surplus helps win IMF approval of programs, while lower foreign exchange reserves (relative to imports) and a currency crisis induce countries to seek an IMF program. Countries in Africa and Asia are less likely to have short-term IMF programs approved. There is no discernible shift in the probability of having an IMF program approved in the 1980s and 1990s compared to earlier periods and, surprisingly, we find no connection between program approval and inflation, real exchange rates, real per 
capita GDP growth or the level of real GDP per capita. Other lagged values were investigated but did not add explanatory power to the model.

There are 862 observations in sample, and the model (at the $25 \%$ predicted probability cut-off point) predicts 71 percent of the observations correctly. But while 80 percent of the "no program participation" observations are correctly predicted, only 34 percent of the "program approval" observations are correctly predicted. At the 10 percent probability cut-off point, however, 96 percent of the "program participation" observations are correctly predicted but only 32 percent of the "no participation" observations. 


\section{$\underline{\text { References }}$}

Bagci, P. and Perraudin, W. 1997. Do IMF Programs Work? Global Economic Institutions Working Paper.

Beveridge, W. and M. Kelly. 1980. Fiscal Content of Financial Programs Supported by Stand-By Arrangements in the Upper Credit Tranches, 1969-78, Staff Papers, International Monetary Fund (Washington), Vol 27 (June 1980), pp. 205-49.

Bird, G. 1996. The International Monetary Fund and developing countries: a review of the evidence and policy options. International Organization 50 (3), pp. 477-511.

Bird, G., Hussain, M. and J. Joyce. 2000. Many Happy Returns? Recidivism and the IMF, Wellesley College Department of Economics Working Paper No. 2000-04 (March).

Bordo, M.D. and H. James. 2000. The International Monetary Fund: Its Present Role in Historical Perspective. NBER Working Paper 7724 (June).

Bordo, M. and A. Schwartz. 2000. Measuring Real Economic Effects of Bailouts: Historical Perspectives on How Countries in Financial Distress Have Fared With and Without Bailouts, NBER Working Paper 7701 (May).

Connors, T. 1979. The Apparent Effects of Recent IMF Stabilization Programs, International Finance Discussion Paper 135 (Washington: Board of Governors of the Federal Reserve System, April 1979).

Conway, P. 1994. IMF Lending Programs: Participation and Impact, Journal of Development Economics 45: 365-391.

Conway, P. 2000. IMF Programs and Economic Crisis: An Empirical Study of Transition. University of North Carolina, Chapel Hill. Manuscript dated January 5, 2000.

Dicks-Mireaux, L., M. Mecagni and S. Schadler. 2000. Evaluating the effect of IMF lending to low-income countries. Journal of Development Economics Vol. 61, pp. 495526.

Dooley, M. 1999. International Financial Architecture and Strategic Default: Can Financial Crises be Less Painful? Manuscript. Paper presented at Carnegie-Rochester Conference (November 19-20, 1999).

Dreher, A. and R. Vaubel. 2001. Does the IMF Cause Moral Hazard and Political Business Cycles? Evidence from Panel Data. Manuscript dated February 2001. University of Mannheim. 
Edwards, S. 1989. The International Monetary Fund and the Developing Countries: A Critical Evaluation, in K. Brunner and A. Meltzer (editors) IMF Policy Advice, Market Volatility, Commodity Price Rules, and Other Essays.

Esquivel, G. and F. Larrain. 1998. Explaining Currency Crises, Mimeo, Harvard Institute for International Development (June).

Frankel, J. and A. Rose. 1996. Currency Crashes in Emerging Markets. An Empirical Treatment, Journal of International Economics 41 (November), pp. 351-366.

Glick, R. and M. Hutchison. 2001. Banking and Currency Crises: How Common Are Twins? In R. Glick, R. Moreno, and M. Spiegel, eds. Financial Crises in Emerging Markets. Cambridge, UK: Cambridge University Press, Chapter 2. Previously issued as Federal Reserve Bank of San Francisco Center for Pacific Basin Studies Working Paper No. PB99-08.

Glick, R. and M. Hutchison. 2000. Capital Controls and Exchange Rate Instability in Developing Economies. Federal Reserve Bank of San Francisco Center for Pacific Basin Studies Working Paper No. PB00-05 (December).

Goldstein, M. and P. Montiel. 1986. Evaluating Fund Stabilization Programs with Multicountry Data: Some Methodological Pitfalls, International Monetary Fund Staff Papers 33 (June), pp. 304-44.

Gupta, P., D. Mishra and R. Sahay. 2000. Output Response During Currency Crises. IMF. Manuscript dated May 2000.

Gylafson, T. 1987. Credit Policy and Economic Activity in Developing Countries with IMF Stabilization Programs, Princeton Essays in International Finance 60 (August).

Heckman, J. 1979. Sample Selection Bias as a Specification Error, Econometrica 47 (January), pp. 153-61.

Joyce, J. 2001. Time Present and Time Past: A Duration Analysis of IMF Programs Spells. Federal Reserve Bank of Boston Working Paper No. 01-02, March.

Kaminsky, G., S. Lizondo, and C. Reinhart. 1998. Leading Indicators of Currency Crises, IMF Staff Papers 45 (March), pp. 1-48.

Kaminsky, G. and C. Reinhart. 1999. The Twin Crises. The Causes of Banking and Balance-of-Payments Problems, American Economic Review 89 (June), pp. 473-500.

Kaplan, E. and D. Rodrik. 2001. Did the Malaysian Capital Controls Work? NBER Working Paper No. W8142, February. 
Khan, M. 1990. The Macroeconomic Effects of Fund-Supported Adjustment Programs, IMF Staff Papers 37, June, pp. 195-231.

Killick, T., M. Malik and M. Manuel. 1992. What Can We Know About the Effects of IMF Programs, The World Economy 15: 575-597.

Knight, M. and J. Santaella. 1997. Economic Determinants of IMF Financial Arrangments. Journal of Development Economics Vol. 54, pp. 405-436.

Lane, T. and S. Phillips. 2000. Does IMF Financing Result in Moral Hazard? IMF Working Paper WP/00/168 (October).

McQuillan, L. and P. Montgomery. 1999. The International Monetary Fund: Financial Medic to the World (editors). Hoover Institution Press, Stanford.

Mussa, M. and M. Savastano. 2000. The IMF Approach to Economic Stabilization, NBER Macroeconomics Annual 1999.

Pastor, M. 1987. The effects of IMF programs in the Third World: Debate and evidence from Latin America, World Development 15 (February), pp. 249-262.

Przeworski, A. and J. Vreeland. 2000. The effect of IMF programs on economic growth, Journal of Development Economics 62, pp. 385-421.

Santaella, J. 1996. Stylized Facts Before IMF-Supported Macroeconomic Adjustment, IMF Staff Papers 43: 502-544.

Stiglitz, J. 2000. What I Learned at the World Economic Crisis. The New Republic April 17.

Willett, T. (forthcoming). Understanding the IMF Debate. The Independent Review: A Journal of Political Economy. 


\section{Table 1}

IMF Programs in Developing Countries - Approvals by Time (1970-1999)

Number of programs approved

(average size of program in million SDRs)

[average size of program relative to GDP] ${ }^{a}$

\begin{tabular}{|c|c|c|c|}
\hline & $\begin{array}{c}\text { Short-Term } \\
\text { Programs } \\
\text { (SBA, ESBA, EFF) }\end{array}$ & $\begin{array}{c}\text { Long-Term } \\
\text { Programs } \\
\text { (SAF, ESAF, PRGF) }\end{array}$ & $\begin{array}{c}\text { All IMF } \\
\text { programs }\end{array}$ \\
\hline $1970-1974$ & $\begin{array}{c}85 \\
(37.12) \\
{[0.9 \%]}\end{array}$ & & 85 \\
\hline $1975-1979$ & $\begin{array}{c}113 \\
(82.66) \\
{[2.0 \%]}\end{array}$ & & 113 \\
\hline $1980-1984$ & $\begin{array}{c}169 \\
(298.42) \\
{[3.9 \%]}\end{array}$ & & 169 \\
\hline $1985-1989$ & $\begin{array}{c}115 \\
(265.78) \\
{[2.2 \%]}\end{array}$ & $\begin{array}{c}58 \\
(87.44) \\
{[4.2 \%]}\end{array}$ & 173 \\
\hline $1990-1994$ & $\begin{array}{c}109 \\
(275.34) \\
{[2.0 \%]}\end{array}$ & $\begin{array}{c}46 \\
(110.62) \\
{[5.8 \%]}\end{array}$ & 155 \\
\hline $1995-1999$ & $\begin{array}{c}87 \\
(1168.48) \\
{[2.2 \%]}\end{array}$ & $\begin{array}{c}63 \\
(148.30) \\
{[7.0 \%]}\end{array}$ & 150 \\
\hline Totals & 678 & 167 & 845 \\
\hline
\end{tabular}

${ }^{\mathrm{a}}$ The size relative to GDP statistic is limited by data availability. 
Table 2

IMF programs - Approvals by Region (1970-1999)

Number of programs approved

(Percent of IMF program by region)

\begin{tabular}{|c|c|c|c|c|}
\hline & SBA & EFF & ESAF & PRGF \\
\hline Totals & 493 & 69 & 113 & 11 \\
\hline Latin America & $\begin{array}{c}146 \\
(29.6 \%)\end{array}$ & $\begin{array}{c}26 \\
(37.7 \%)\end{array}$ & $\begin{array}{c}13 \\
(11.5 \%)\end{array}$ & $\begin{array}{c}1 \\
(9 \%)\end{array}$ \\
\hline Middle East & $\begin{array}{c}14 \\
(2.8 \%)\end{array}$ & $\begin{array}{c}6 \\
(8.7 \%)\end{array}$ & $\begin{array}{c}1 \\
(.88 \%)\end{array}$ & $\begin{array}{c}0 \\
(0 \%)\end{array}$ \\
\hline East and South Asia & $\begin{array}{c}62 \\
(12.6 \%)\end{array}$ & $\begin{array}{c}12 \\
(17.4 \%)\end{array}$ & $\begin{array}{c}12 \\
(10.6 \%)\end{array}$ & $\begin{array}{c}1 \\
(9 \%)\end{array}$ \\
\hline Africa & $\begin{array}{c}177 \\
(35.9 \%)\end{array}$ & $\begin{array}{c}16 \\
(23.2 \%)\end{array}$ & $\begin{array}{c}77 \\
(68.1 \%)\end{array}$ & $\begin{array}{c}9 \\
(82 \%)\end{array}$ \\
\hline $\begin{array}{l}\text { Eastern Europe and } \\
\text { the former USSR }\end{array}$ & $\begin{array}{c}68 \\
(13.8 \%)\end{array}$ & $\begin{array}{c}8 \\
(11.6 \%)\end{array}$ & $\begin{array}{c}9 \\
(8 \%)\end{array}$ & \\
\hline Other & $\begin{array}{c}26 \\
(5.3 \%)\end{array}$ & $\begin{array}{c}1 \\
(1.4 \%)\end{array}$ & $\begin{array}{c}1 \\
(.88 \%)\end{array}$ & $\begin{array}{c}0 \\
(0 \%)\end{array}$ \\
\hline
\end{tabular}


Table 3

\begin{tabular}{|l|c|}
\hline \multicolumn{2}{|l|}{ Panel A } \\
\hline $\begin{array}{l}\text { \% of short-term IMF programs } \\
\text { associated with a contemporaneous } \\
\text { currency crisis }\end{array}$ & 18 \\
\hline $\begin{array}{l}\text { \% of currency crisis associated with a } \\
\text { contemporaneous short-term IMF } \\
\text { program }\end{array}$ & 28 \\
\hline $\begin{array}{l}\text { Chi independence test for } \\
\text { contemporaneous IMF and currency } \\
\text { crisis series }\end{array}$ & $\mathbf{0 . 0 0 0 4}$ \\
\hline \begin{tabular}{l} 
Panel B \\
\hline $\begin{array}{l}\text { \% of short-term IMF programs } \\
\text { associated with a contemporaneous or }\end{array}$
\end{tabular} & $\mathbf{3 3}$ \\
$\begin{array}{l}\text { lagged (t-1) currency crisis } \\
\text { \% of contemporaneous or lagged (t-1) } \\
\text { currency crisis associated with a } \\
\text { short-term IMF program }\end{array}$ & $\mathbf{2 8}$ \\
\hline $\begin{array}{l}\text { Chi independence test for } \\
\text { contemporaneous IMF and currency } \\
\text { crisis series }\end{array}$ & $\mathbf{0 . 0 0 0 0}$ \\
\hline
\end{tabular}


Table 4

\section{Summary Statistics - Short Term IMF programs \\ means}

(t-statistic for difference in means with the column to the left)

[Number of observations]

\begin{tabular}{|c|c|c|c|c|c|}
\hline \multirow{2}{*}{ Variables } & \multicolumn{2}{|c|}{$\begin{array}{l}\text { All countries } \\
\text { (67 countries) }\end{array}$} & \multicolumn{2}{|c|}{$\begin{array}{l}\text { IMF participating countries } \\
\text { (60 countries) }\end{array}$} & \multirow{2}{*}{$\begin{array}{c}\text { Non-IMF } \\
\text { countries } \\
\text { All years }\end{array}$} \\
\hline & $\begin{array}{c}\text { Non program } \\
\text { years }\end{array}$ & $\begin{array}{l}\text { Program } \\
\text { years }\end{array}$ & $\begin{array}{c}\text { Non program } \\
\text { years }\end{array}$ & All years & \\
\hline Real GDP growth & $\begin{array}{r}4.18 \\
{[1082]}\end{array}$ & $\begin{array}{c}2.94 \\
\left(4.83^{\star * *}\right) \\
{[585]}\end{array}$ & $\begin{array}{c}3.62 \\
\left(-2.62^{* * *}\right) \\
{[895]}\end{array}$ & $\begin{array}{c}3.36 \\
(1.28) \\
{[1480]}\end{array}$ & $\begin{array}{c}6.83 \\
\left(-9.10^{* * *}\right) \\
{[187]}\end{array}$ \\
\hline Inflation & $\begin{array}{r}18.43 \\
{[1061]}\end{array}$ & $\begin{array}{c}25.01 \\
(-3.09 * * *) \\
{[549]}\end{array}$ & $\begin{array}{c}20.29 \\
\left(2.05^{\star}\right) \\
{[897]}\end{array}$ & $\begin{array}{l}22.08 \\
(-0.99) \\
{[1446]}\end{array}$ & $\begin{array}{c}8.26 \\
\left(4.16^{\star \star *}\right) \\
{[164]}\end{array}$ \\
\hline $\begin{array}{l}\text { Current account to GDP } \\
\text { ratio (\%) }\end{array}$ & [858] & $\begin{array}{l}-5.01 \\
(-0.14) \\
{[473]}\end{array}$ & $\begin{array}{l}-5.81 \\
(1.28) \\
{[719]}\end{array}$ & $\begin{array}{c}-5.49 \\
(-0.60) \\
{[1192]}\end{array}$ & $\begin{array}{c}-0.01 \\
\left(-4.33^{* * *}\right) \\
{[139]}\end{array}$ \\
\hline Credit growth & {$[1074]$} & $\begin{array}{c}26.71 \\
(-0.77) \\
{[567]}\end{array}$ & $\begin{array}{l}26.19 \\
(0.24) \\
{[917]}\end{array}$ & $\begin{array}{l}26.39 \\
(-0.11) \\
{[1484]}\end{array}$ & $\begin{array}{c}18.75 \\
(2.28 * *) \\
{[157]}\end{array}$ \\
\hline $\begin{array}{l}\text { Budget surplus to GDP } \\
\text { ratio (\%) }\end{array}$ & [952] & $\begin{array}{c}-4.44 \\
\left(3.22^{\star \star *}\right) \\
{[507]}\end{array}$ & $\begin{array}{c}-4.04 \\
(-1.19) \\
{[796]}\end{array}$ & $\begin{array}{l}-4.20 \\
(0.59) \\
{[1303]}\end{array}$ & $\begin{array}{c}0.00 \\
\left(-8.52^{* * *}\right) \\
{[156]}\end{array}$ \\
\hline
\end{tabular}

a the countries that have never participated in a short-term IMF program (either SBA or EFF), and that are included in our data-set, are: Botswana, Hong-Kong, Malta, Malaysia, Paraguay, Singapore and Swaziland. 


\section{Table 5}

Before/After Summary Statistics - IMF short term programs - 4 year window means

(t-statistic for difference in means with the column to the left)

[t-statistic for difference in means with the first column]

(Number of observations)

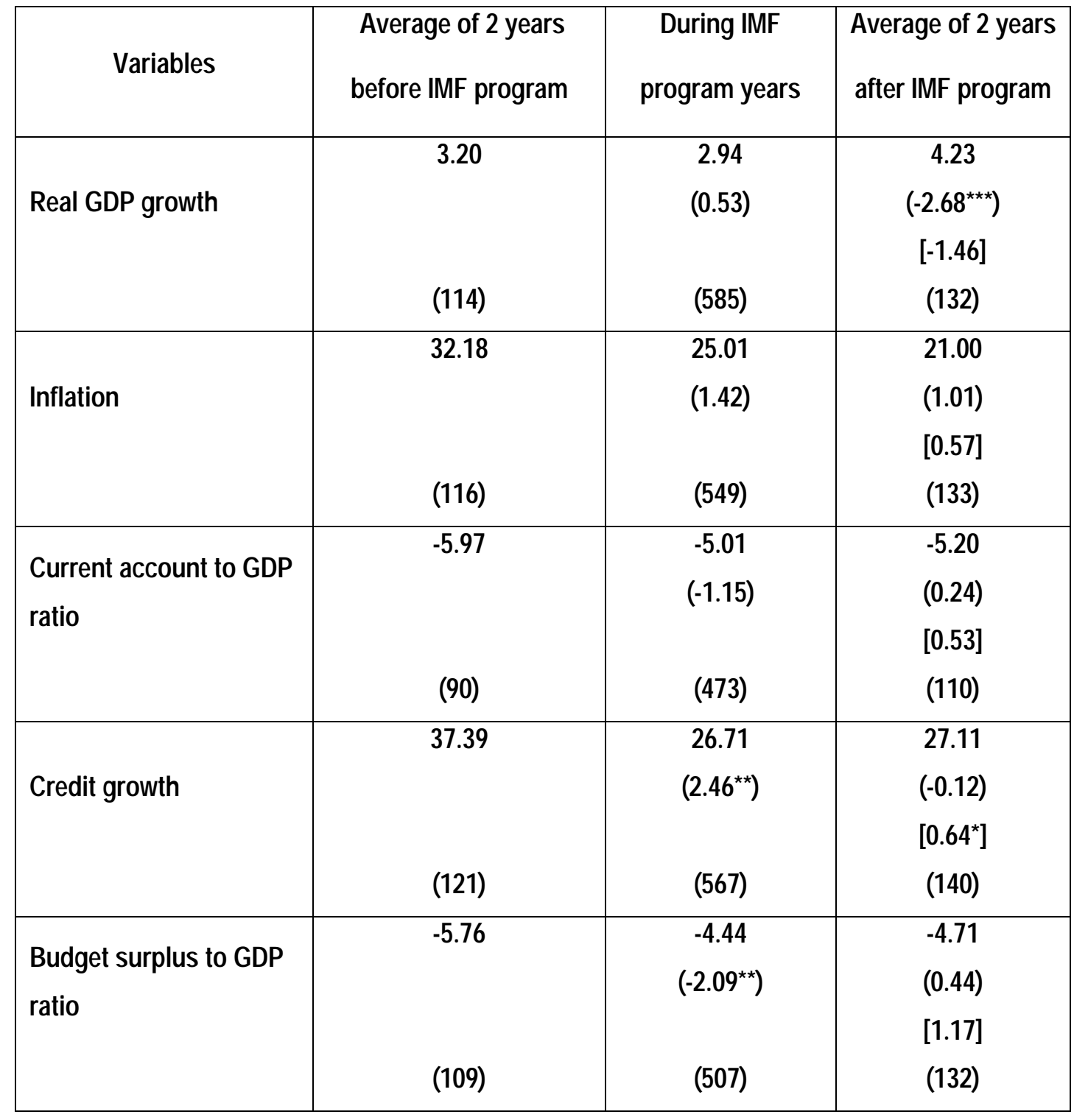




\section{Table 6}

Before/After Summary Statistics - IMF short term programs - 2 year window

Mean values

(t-statistic for difference in means with the column to the left)

[t-statistic for difference in means with the first column]

(Number of observations)

\begin{tabular}{|c|c|c|c|}
\hline Variables & $\begin{array}{l}1 \text { year before } \\
\text { IMF program }\end{array}$ & $\begin{array}{c}\text { During IMF } \\
\text { program years }\end{array}$ & $\begin{array}{c}1 \text { year after IMF } \\
\text { program }\end{array}$ \\
\hline Real GDP growth & $\begin{array}{l}2.62 \\
(76)\end{array}$ & $\begin{array}{c}2.94 \\
(-0.56) \\
(585)\end{array}$ & $\begin{array}{c}4.34 \\
\left(-2.47^{\star *}\right) \\
{\left[-1.98^{\star \star}\right]} \\
(84)\end{array}$ \\
\hline Inflation & $\begin{array}{r}32.28 \\
(76)\end{array}$ & $\begin{array}{l}25.01 \\
(1.24) \\
(549)\end{array}$ & $\begin{array}{c}21.71 \\
(0.68) \\
{[1.15]} \\
(85)\end{array}$ \\
\hline $\begin{array}{l}\text { Current account to } \\
\text { GDP ratio }\end{array}$ & $\begin{array}{r}-5.23 \\
(59)\end{array}$ & $\begin{array}{c}-5.01 \\
(-0.24) \\
(473)\end{array}$ & $\begin{array}{c}-4.18 \\
(-0.84) \\
{[-0.63]} \\
(68)\end{array}$ \\
\hline Credit growth & $\begin{array}{l}39.38 \\
(79)\end{array}$ & 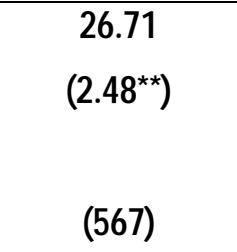 & $\begin{array}{c}28.98 \\
(-0.54) \\
{[1.22]} \\
(88)\end{array}$ \\
\hline $\begin{array}{l}\text { Budget surplus to } \\
\text { GDP ratio }\end{array}$ & $\begin{array}{l}-5.98 \\
(70)\end{array}$ & $\begin{array}{c}-4.44 \\
\left(-2.07^{\star \star}\right) \\
(507)\end{array}$ & $\begin{array}{c}-4.46 \\
(0.02) \\
{[-1.44]} \\
(75)\end{array}$ \\
\hline
\end{tabular}


Table 7

Output Growth Equation Estimates

Dependent Variable: real GDP growth rate

\begin{tabular}{|c|c|c|c|c|c|}
\hline \multirow[t]{2}{*}{ Variables $^{\mathrm{a}}$} & \multicolumn{5}{|c|}{$\begin{array}{l}\text { Coefficients } \\
\text { (t-statistics) }\end{array}$} \\
\hline & (1) & (2) & (3) & (4) & (5) \\
\hline Constant & $\begin{array}{c}3.787^{\star \star \star} \\
(8.02)\end{array}$ & $\begin{array}{c}4.169^{* \star *} \\
(7.52)\end{array}$ & $\begin{array}{c}4.164^{\star \star *} \\
(7.37)\end{array}$ & $\begin{array}{c}4.444^{\star * *} \\
(7.70)\end{array}$ & $\begin{array}{c}4.147^{* \star *} \\
(7.43)\end{array}$ \\
\hline Change in budget surplus/GDP ratio (t-1) & $\begin{array}{c}13.607^{\star \star \star} \\
(3.31)\end{array}$ & $\begin{array}{l}7.412^{*} \\
(1.89)\end{array}$ & $\begin{array}{l}7.213^{*} \\
(1.81)\end{array}$ & $\begin{array}{l}7.266^{\star} \\
(1.82)\end{array}$ & $\begin{array}{l}7.254^{*} \\
(1.81)\end{array}$ \\
\hline Inflation (t-1) & $\begin{array}{l}-0.005 \\
(-0.82)\end{array}$ & $\begin{array}{l}0.003 \\
(0.56)\end{array}$ & $\begin{array}{l}0.003 \\
(0.55)\end{array}$ & $\begin{array}{l}0.002 \\
(0.46)\end{array}$ & $\begin{array}{l}0.003 \\
(0.61)\end{array}$ \\
\hline Credit growth (t-1) & $\begin{array}{l}-0.009 \\
(-1.55)\end{array}$ & $\begin{array}{c}-0.009 * * \\
(-2.14)\end{array}$ & $\begin{array}{c}-0.009^{* *} \\
(-2.08)\end{array}$ & $\begin{array}{c}-0.009 * * \\
(-2.03)\end{array}$ & $\begin{array}{c}-0.010^{\star *} \\
(-2.13)\end{array}$ \\
\hline Real GDP growth (t-1) & $\begin{array}{l}0.094 \\
(1.34)\end{array}$ & $\begin{array}{l}0.139 * * \\
(2.25)\end{array}$ & $\begin{array}{l}0.146^{* *} \\
(2.31)\end{array}$ & $\begin{array}{l}0.150^{* *} \\
(2.39)\end{array}$ & $\begin{array}{l}0.148^{\star *} \\
(2.32)\end{array}$ \\
\hline $\begin{array}{l}\text { External growth rates (t-1) } \\
\text { (weighted average) }\end{array}$ & $\begin{array}{c}0.275^{\star \star \star} \\
(3.17)\end{array}$ & $\begin{array}{c}0.253^{* * *} \\
(2.69)\end{array}$ & $\begin{array}{c}0.255^{* * *} \\
(2.71)\end{array}$ & $\begin{array}{c}0.268^{* * *} \\
(2.82)\end{array}$ & $\begin{array}{c}0.259 * \star * \\
(2.75)\end{array}$ \\
\hline Real exchange rate overvaluation (t-1) & $\begin{array}{c}-0.030^{\star \star \star} \\
(-4.37)\end{array}$ & $\begin{array}{c}-0.033^{* * *} \\
(-4.19)\end{array}$ & $\begin{array}{c}-0.030^{* * *} \\
(-3.66)\end{array}$ & $\begin{array}{c}-0.030^{* * *} \\
(-3.61)\end{array}$ & $\begin{array}{c}-0.030^{* * *} \\
(-3.49)\end{array}$ \\
\hline $\begin{array}{l}\text { IMF participation dummy for Short-Term } \\
\text { programs }(t)\end{array}$ & $\begin{array}{c}-1.010^{\star \star \star} \\
(-3.37)\end{array}$ & $\begin{array}{l}-0.740^{*} \\
(-1.87)\end{array}$ & $\begin{array}{c}-0.781^{* *} \\
(-2.02)\end{array}$ & $\begin{array}{l}-0.659 \\
(-1.44)\end{array}$ & $\begin{array}{l}-0.749^{*} \\
(-1.82)\end{array}$ \\
\hline Currency crises dummy (t-1) & & $\begin{array}{c}-1.496 * * * \\
(-3.32)\end{array}$ & $\begin{array}{c}-1.161^{\text {*** }} \\
(-2.80)\end{array}$ & $\begin{array}{c}-1.107^{* *} \\
(-2.39)\end{array}$ & $\begin{array}{c}-1.089^{* *} \\
(-2.34)\end{array}$ \\
\hline Currency crises dummy $(t)$ & & & $\begin{array}{c}-0.805^{* *} \\
(-1.89)\end{array}$ & $\begin{array}{l}-0.765^{*} \\
(-1.65)\end{array}$ & $\begin{array}{l}-0.761^{*} \\
(-1.64)\end{array}$ \\
\hline $\begin{array}{l}\text { Lagged+contemporary interactive term } \\
D_{i t}^{i m f} * D_{i ; t, o r(t-1)}^{c c}\end{array}$ & & & & $\begin{array}{l}-0.195 \\
(-0.30)\end{array}$ & $\begin{array}{l}-0.202 \\
(-0.32)\end{array}$ \\
\hline $\begin{array}{l}\text { Dynamics for IMF participation dummy } \\
\text { for Short-Term programs }{ }^{b}(t-1, t-2, t-3)\end{array}$ & & & & & $\begin{array}{l}-0.457 \\
(0.10)\end{array}$ \\
\hline Adjusted R-squared & 0.12 & 0.22 & 0.23 & 0.22 & 0.22 \\
\hline Number of observations & 1128 & 966 & 958 & 958 & 958 \\
\hline Durbin-Watson Statistic & 1.61 & 2.00 & 1.99 & 1.98 & 1.98 \\
\hline
\end{tabular}

a all regressions, except the first, include country dummies. ${ }^{b}$ sum of the coefficients of the IMF dummy lagged for t-1, t-

2 and $\mathrm{t}-3$ (t-statistic on sum of lags reported). F-statistic (joint significance of three lagged values) is 0.86 . 


\section{Table 8}

Output Growth Equation - Extensions

Dependent Variable: real GDP growth rate

\begin{tabular}{|c|c|c|c|c|}
\hline \multirow[t]{2}{*}{ Variables $^{\text {a }}$} & \multicolumn{4}{|c|}{$\begin{array}{l}\text { Coefficients } \\
\text { (t statistics) }\end{array}$} \\
\hline & \multicolumn{2}{|c|}{ Standard dating } & \multicolumn{2}{|c|}{ Alternative dating } \\
\hline Constant & $\begin{array}{c}4.171^{\star \star \star} \\
(7.36)\end{array}$ & $\begin{array}{c}4.068^{\star \star \star} \\
(7.29)\end{array}$ & $\begin{array}{c}4.159^{\star \star \star} \\
(7.48)\end{array}$ & $\begin{array}{c}4.032^{\star \star \star} \\
(7.26)\end{array}$ \\
\hline Change in budget surplus/GDP ratio (t-1) & $\begin{array}{l}7.08^{\star} \\
(1.77)\end{array}$ & $\begin{array}{l}6.912^{*} \\
(1.71)\end{array}$ & $\begin{array}{l}7.042^{*} \\
(1.78)\end{array}$ & $\begin{array}{l}6.635^{*} \\
(1.64)\end{array}$ \\
\hline Inflation (t-1) & $\begin{array}{l}0.003 \\
(0.56)\end{array}$ & $\begin{array}{l}0.003 \\
(0.54)\end{array}$ & $\begin{array}{l}0.003 \\
(0.57)\end{array}$ & $\begin{array}{l}0.003 \\
(0.56)\end{array}$ \\
\hline Credit growth (t-1) & $\begin{array}{l}-0.009^{* *} \\
(-2.11)\end{array}$ & $\begin{array}{l}-0.009^{* *} \\
(-2.12)\end{array}$ & $\begin{array}{l}-0.009^{\star *} \\
(-2.10)\end{array}$ & $\begin{array}{l}-0.009^{* \star} \\
(-2.12)\end{array}$ \\
\hline Real GDP growth (t-1) & $\begin{array}{l}0.146^{* *} \\
(2.33)\end{array}$ & $\begin{array}{l}0.150^{* *} \\
(2.41)\end{array}$ & $\begin{array}{l}0.147^{* *} \\
(2.36)\end{array}$ & $\begin{array}{l}0.152^{* *} \\
(2.42)\end{array}$ \\
\hline $\begin{array}{l}\text { External growth rates (t-1) } \\
\text { (weighted average) }\end{array}$ & $\begin{array}{c}0.253^{\star \star *} \\
(2.69)\end{array}$ & $\begin{array}{c}0.264^{* \star *} \\
(2.81)\end{array}$ & $\begin{array}{c}0.252^{\star * *} \\
(2.72)\end{array}$ & $\begin{array}{c}0.267^{\star \star *} \\
(2.85)\end{array}$ \\
\hline Real exchange rate overvaluation (t-1) & $\begin{array}{l}-0.030^{\star \star \star} \\
(-3.62)\end{array}$ & $\begin{array}{c}-0.029 * \star \star \\
(-3.42)\end{array}$ & $\begin{array}{c}-0.030^{* * *} \\
(-3.53)\end{array}$ & $\begin{array}{c}-0.029^{\star * \star} \\
(-3.44)\end{array}$ \\
\hline IMF program participation dummy (t) & $\begin{array}{l}-0.647^{\star} \\
(-1.77)\end{array}$ & & $\begin{array}{l}-1.217^{\star \star} \\
(-2.71)\end{array}$ & \\
\hline Lead IMF program participation dummy ( $t+1)$ & $\begin{array}{l}-0.266 \\
(-0.69)\end{array}$ & & $\begin{array}{l}0.303 \\
(0.73)\end{array}$ & \\
\hline IMF program approval dummy (t) & & $\begin{array}{l}-0.878^{*} \\
(-1.93)\end{array}$ & & $\begin{array}{l}-0.583 \\
(-1.51)\end{array}$ \\
\hline Lead IMF program approval dummy $(t+1)$ & & $\begin{array}{l}-0.550 \\
(-1.42)\end{array}$ & & $\begin{array}{l}0.305 \\
(0.74)\end{array}$ \\
\hline Currency crises dummy (t-1) & $\begin{array}{c}-1.137^{\star \star \star} \\
(-2.72)\end{array}$ & $\begin{array}{c}-1.178 * \star \star \\
(-2.86)\end{array}$ & $\begin{array}{c}-1.110^{\star \star \star} \\
(-2.67)\end{array}$ & $\begin{array}{c}-1.228^{\star \star \star} \\
(-2.98)\end{array}$ \\
\hline Currency crises dummy (t) & $\begin{array}{l}-0.778^{*} \\
(-1.84)\end{array}$ & $\begin{array}{l}-0.643 \\
(-1.52)\end{array}$ & $\begin{array}{c}-0.772^{*} \\
(-1.83)\end{array}$ & $\begin{array}{l}-0.783^{*} \\
(-1.83)\end{array}$ \\
\hline Adjusted R-squared & 0.23 & 0.23 & 0.23 & 0.22 \\
\hline Number of observations & 958 & 958 & 958 & 958 \\
\hline Durbin-Watson Statistic & 1.99 & 2.00 & 1.99 & 2.00 \\
\hline
\end{tabular}

a all regressions include country dummies. 
Table 9

Policy Reaction Function Estimates

Dependent Variable: credit growth

\begin{tabular}{|c|c|c|c|c|c|}
\hline \multirow[b]{2}{*}{ Explanatory Variables ${ }^{a}$} & \multicolumn{5}{|c|}{$\begin{array}{l}\text { Coefficients } \\
\text { (t-statistics) }\end{array}$} \\
\hline & $\begin{array}{c}\text { All years } \\
\text { (1) }\end{array}$ & $\begin{array}{c}\text { Program } \\
\text { years } \\
\text { (2) }\end{array}$ & $\begin{array}{c}\text { Non-program } \\
\text { years } \\
\text { (3) }\end{array}$ & (4) & (5) \\
\hline Constant & $\begin{array}{c}10.252^{* * *} \\
(4.23)\end{array}$ & $\begin{array}{l}6.892 \\
(1.39)\end{array}$ & $\begin{array}{c}28.769 * \star * \\
(4.46)\end{array}$ & $\begin{array}{c}40.045^{\star * \star} \\
(4.55)\end{array}$ & $\begin{array}{c}39.857^{* \star \star} \\
(4.67)\end{array}$ \\
\hline $\begin{array}{l}\text { Change in current account to GDP } \\
\text { ratio (t-1) }\end{array}$ & $\begin{array}{r}-11.720 \\
(-0.49)\end{array}$ & $\begin{array}{l}48.131 \\
(0.87)\end{array}$ & $\begin{array}{c}-67.246 * * \\
(-2.05)\end{array}$ & $\begin{array}{c}-19.938 \\
(-0.89)\end{array}$ & $\begin{array}{c}-18.511 \\
(-0.83)\end{array}$ \\
\hline Inflation (t-1) & $\begin{array}{c}0.615^{\star \star \star} \\
(4.97)\end{array}$ & $\begin{array}{c}0.641^{* * *} \\
(3.06)\end{array}$ & $\begin{array}{c}0.661^{* * *} \\
(4.24)\end{array}$ & $\begin{array}{c}0.390 * * * \\
(2.86)\end{array}$ & $\begin{array}{c}0.394^{* * *} \\
(2.95)\end{array}$ \\
\hline Real GDP growth (t-1) & $\begin{array}{l}0.063 \\
(0.22)\end{array}$ & $\begin{array}{l}0.024 \\
(0.09)\end{array}$ & $\begin{array}{l}-0.385 \\
(-0.78)\end{array}$ & $\begin{array}{l}-0.267 \\
(-1.08)\end{array}$ & $\begin{array}{l}-0.277 \\
(-1.13)\end{array}$ \\
\hline Autocracy & $\begin{array}{l}-0.337 \\
(-1.17) \\
\end{array}$ & $\begin{array}{l}-0.022 \\
(-0.06) \\
\end{array}$ & $\begin{array}{l}-0.511 \\
(-1.11) \\
\end{array}$ & $\begin{array}{l}0.409 \\
(1.32) \\
\end{array}$ & $\begin{array}{l}0.509^{*} \\
(1.64) \\
\end{array}$ \\
\hline Africa dummy & $\begin{array}{l}-0.520 \\
(-0.19)\end{array}$ & $\begin{array}{l}-0.544 \\
(-0.15)\end{array}$ & $\begin{array}{l}-6.897 \\
(-1.47)\end{array}$ & $\begin{array}{c}-33.074^{* * \star} \\
(-4.03)\end{array}$ & $\begin{array}{c}-35.168^{\star \star *} \\
(-4.33)\end{array}$ \\
\hline Asia dummy & $\begin{array}{l}3.328^{* *} \\
(2.00)\end{array}$ & $\begin{array}{l}4.411 \\
(1.51)\end{array}$ & $\begin{array}{l}0.163 \\
(0.08)\end{array}$ & $\begin{array}{c}-23.709 * * \star \\
(-2.82)\end{array}$ & $\begin{array}{c}-24.277^{* * *} \\
(-2.97)\end{array}$ \\
\hline Latin America dummy & $\begin{array}{l}4.558^{* *} \\
(2.24)\end{array}$ & $\begin{array}{l}6.738^{*} \\
(1.73)\end{array}$ & $\begin{array}{l}5.228^{*} \\
(1.77)\end{array}$ & $\begin{array}{c}-25.626^{* * *} \\
(-3.30)\end{array}$ & $\begin{array}{l}-25.463^{\star * \star} \\
(-3.36)\end{array}$ \\
\hline $\begin{array}{l}\text { Inverse Mills Ratio, IMR } \\
\text { (sample selection correction) }\end{array}$ & & $\begin{array}{l}1.373 \\
(0.75)\end{array}$ & $\begin{array}{c}49.661^{* * *} \\
(3.40)\end{array}$ & & \\
\hline IMF participation dummy (t) & & & & $\begin{array}{l}-3.942^{\star} \\
(-1.84)\end{array}$ & $\begin{array}{l}-1.285 \\
(-0.67) \\
\end{array}$ \\
\hline Currency crises dummy (t-1) & $\begin{array}{l}3.737 \\
(1.06) \\
\end{array}$ & $\begin{array}{r}-3.315 \\
(0.64) \\
\end{array}$ & $\begin{array}{c}19.210^{* * *} \\
(3.01)\end{array}$ & $\begin{array}{l}3.798 \\
(1.16)\end{array}$ & $\begin{array}{c}11.326^{* *} \\
(2.19)\end{array}$ \\
\hline $\begin{array}{l}\text { Interactive term } \\
\left(D_{i t}^{i m f} * D_{i(t-1)}^{c c}\right)\end{array}$ & & & & & $\begin{array}{c}-15.645^{\star *} \\
(-2.44)\end{array}$ \\
\hline Adjusted R-squared & 0.38 & 0.47 & 0.41 & 0.44 & 0.44 \\
\hline Number of observations & 987 & 322 & 505 & 987 & 987 \\
\hline Durbin-Watson Statistic & 1.73 & 1.27 & 1.92 & 1.81 & 1.83 \\
\hline
\end{tabular}

\footnotetext{
${ }^{\text {a }}$ columns 4-5 regressions also include country dummies.
} 
Figure 1 - Real GDP Growth in East Asia

1998 - Predicted Values and Forecast Error
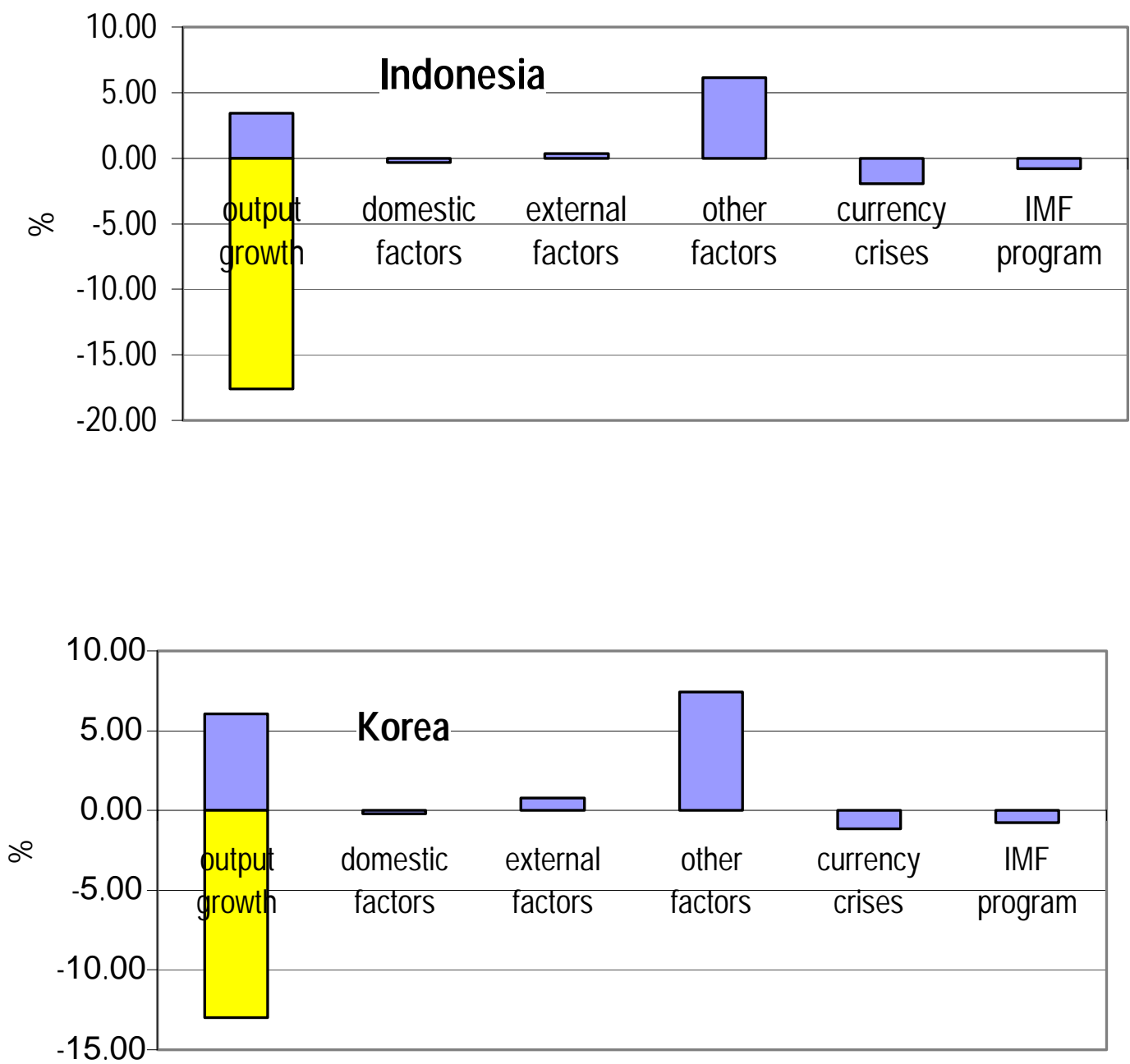

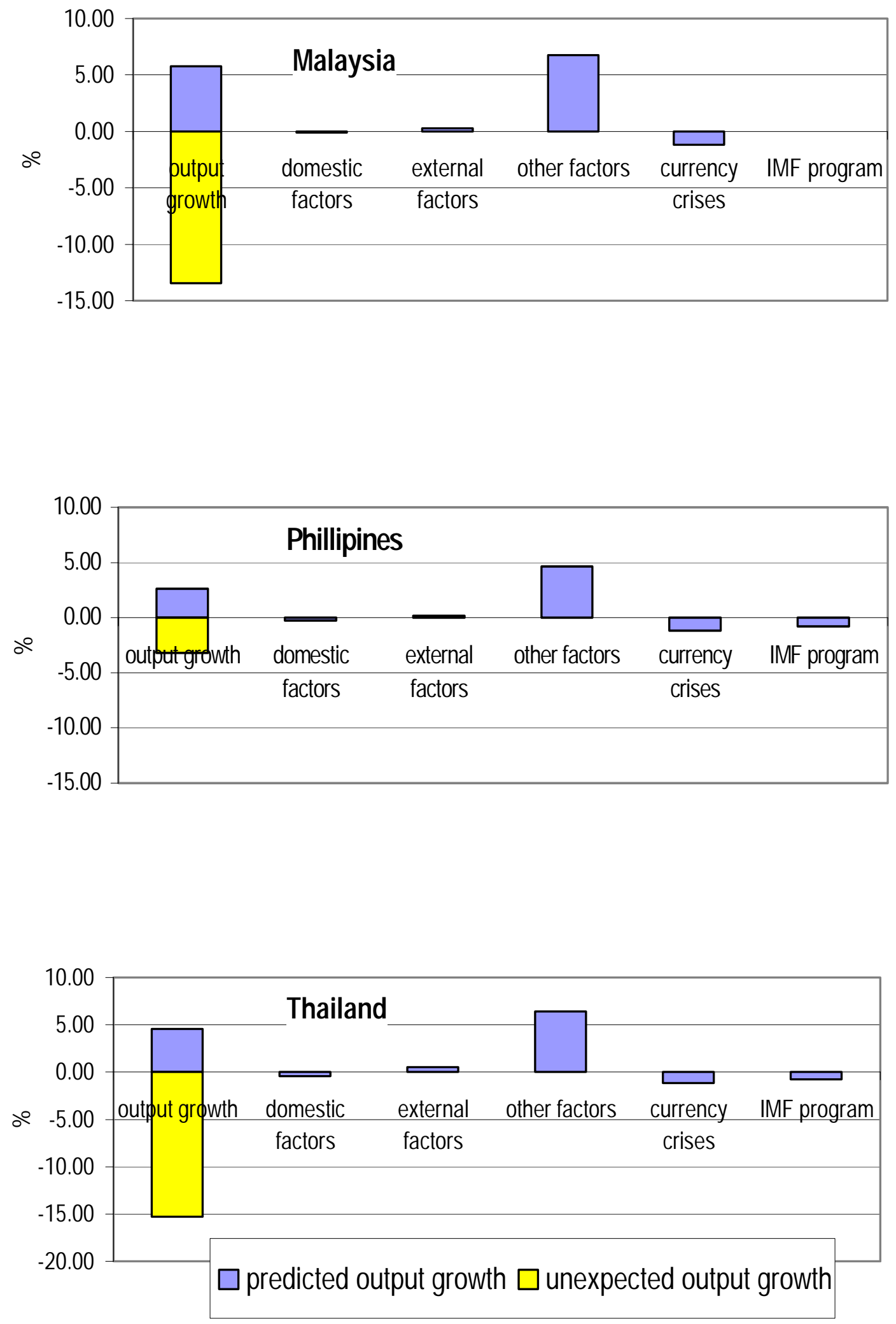
Appendix - Table 1

Countries Included in Data-set

\begin{tabular}{l|ll}
\multicolumn{1}{c|}{$\begin{array}{c}\text { Emerging Markets } \\
\text { (25 countries) }\end{array}$} & \multicolumn{2}{|c}{ Other Developing Countries } \\
Argentina & Bangladesh & \multicolumn{1}{c}{ Mali } \\
Brazil & Belize & Morocco \\
Chile & Bolivia & Mozambique \\
Colombia & Botswana & Myanmar \\
Costa Rica & Burundi & Nepal \\
Cyprus & Cameroon & Nicaragua \\
Dominican Republic & Ecuador & Nigeria \\
Hong Kong & Egypt & Pakistan \\
Indonesia & El Salvador & Paraguay \\
Jordan & Equatorial Guinea & Peru \\
Korea & Ethiopia & Sierra Leone \\
Malaysia & Fiji & Sri Lanka \\
Malta & Ghana & Swaziland \\
Mauritius & Grenada & Syrian Arab Rep. \\
Mexico & Guatemala & Uganda \\
Panama & Guinea-Bissau & Zambia \\
Philippines & Guyana & Zimbabwe \\
Singapore & Haiti & \\
South Africa & Honduras & \\
Thailand & India & \\
Trinidad and Tobago & Jamaica & \\
Tunisia & Kenya & \\
Turkey & Lao P.D. Rep. & \\
Uruguay & Madagascar & \\
Venezuela & Malawi & \\
& & \\
&
\end{tabular}




\section{Appendix - Table 2}

\section{Occurrences of Currency Crises and IMF program participation}

\begin{tabular}{|c|c|c|}
\hline & $\begin{array}{l}\text { Currency } \\
\text { Crises }^{1}\end{array}$ & IMF programs² $^{2}$ \\
\hline Argentina & $1975,1982,1989$ & $\begin{array}{l}\text { 1972f, 1973f, 1975f, 1976a, 1976f, 1977a, } \\
\text { 1983a, 1984a, 1987a, 1989a, 1991a, 1992b, } \\
\text { 1996a }\end{array}$ \\
\hline Bolivia & $\begin{array}{l}\text { 1981, 1983, 1988, } \\
1991\end{array}$ & 1973a, 1980a, 1986a, 1986c, 1988c, 1994c \\
\hline Brazil & $\begin{array}{l}\text { 1982, 1987, 1990, } \\
1995\end{array}$ & 1970a, 1971a, 1972a, 1983b, 1988a, 1992a \\
\hline Chile & 1985 & $\begin{array}{l}\text { 1970a, 1972f, 1973f, 1974a, 1975a, 1985b, } \\
\text { 1989a }\end{array}$ \\
\hline Columbia & 1985 & 1970a, 1971a, 1972a, 1973a \\
\hline Costa Rica & 1981 & $\begin{array}{l}\text { 1976a, 1980a, 1981b, 1982a, 1985a, 1987a, } \\
\text { 1989a, 1991a, 1993a, 1995a }\end{array}$ \\
\hline $\begin{array}{l}\text { Dominican } \\
\text { Republic }\end{array}$ & $1985,1987,1990$ & 1983b, 1985a, 1991a, 1993a \\
\hline Ecuador & $1982,1985,1988$ & $\begin{array}{l}\text { 1970a, 1972a, 1983a, 1985a, 1986a, 1988a, } \\
\text { 1989a, 1991a, 1994a }\end{array}$ \\
\hline El Salvador & 1986,1990 & $\begin{array}{l}\text { 1970a, 1972a, 1980a, 1982a, 1990a, 1992a, } \\
\text { 1993a, 1995a, 1997a }\end{array}$ \\
\hline Guatemala & 1986, 1989 & 1970a, 1972a, 1981a, 1983a, 1988a, 1992a \\
\hline Haiti & 1977,1991 & $\begin{array}{l}\text { 1970a, 1971a, 1972a, 1973a, 1974a, 1975a, } \\
\text { 1976a, 1977a, 1978b, 1982a, 1983a, 1986c, } \\
\text { 1989a, 1995a, 1996d }\end{array}$ \\
\hline Honduras & 1990 & 1971a, 1972a, 1979b, 1982a, 1990a, 1992c \\
\hline Mexico & $\begin{array}{l}1976,1982,1985 \\
1994\end{array}$ & 1977b, 1983b, 1986a, 1989b, 1995a \\
\hline Nicaragua & 1993 & 1970a, 1972a, 1979a, 1991a, 1994c \\
\hline Panama & & $\begin{array}{l}\text { 1970a, 1971a, 1972a, 1973a, 1974a, 1975a, } \\
\text { 1977a, 1978a, 1979a, 1980a, 1982a, 1983a, } \\
\text { 1985a, 1992a, 1995a, 1997b }\end{array}$ \\
\hline Paraguay & $\begin{array}{l}1984,1986,1988 \\
1992\end{array}$ & \\
\hline Peru & $1976,1979,1987$ & $\begin{array}{l}\text { 1970a, 1977a, 1978a, 1979a, 1982b, 1984a, } \\
\text { 1993b, 1996b }\end{array}$ \\
\hline Uruguay & 1982 & $\begin{array}{l}\text { 1970a, 1972a, 1972f, 1975a, 1976a, 1976f, } \\
\text { 1977a, 1979a, 1980a, 1981a, 1983a, 1985a, } \\
\text { 1990a, 1992a, 1996a, 1997a }\end{array}$ \\
\hline Venezuela & $\begin{array}{l}1984,1986,1989, \\
1994\end{array}$ & 1989b, 1996a \\
\hline Grenada & 1978 & 1975a, 1979a, 1981a, 1983b \\
\hline
\end{tabular}




\begin{tabular}{|c|c|c|}
\hline Guyana & 1987,1989 & $\begin{array}{l}\text { 1970a, 1971a, 1972a, 1973a, 1974a, 1974f, } \\
\text { 1975a, 1976a, 1978a, 1979b, 1980b, 1990a, } \\
\text { 1990c, 1994c }\end{array}$ \\
\hline Belize & & $1984 a$ \\
\hline Jamaica & $1978,1983,1990$ & $\begin{array}{l}\text { 1973a, 1974f, 1977a, 1978b, 1979b, 1981b, } \\
\text { 1984a, 1987a, 1988a, 1990a, 1991a, 1992b }\end{array}$ \\
\hline Trinidad \& Tobago & 1985, 1988, 1993 & 1989a, 1990a \\
\hline Cyprus & & $1980 a$ \\
\hline Jordan & $\begin{array}{l}\text { 1983, 1987, 1989, } \\
1992\end{array}$ & 1972f, 1973f, 1989a, 1992a, 1994b, 1996b \\
\hline $\begin{array}{l}\text { Syrian Arab } \\
\text { Republic }\end{array}$ & $1977,1982,1988$ & $1972 f$ \\
\hline Egypt & 1979,1989 & $\begin{array}{l}\text { 1973f, 1977a, 1978b, 1987a, 1991a, 1993b, } \\
\text { 1996a }\end{array}$ \\
\hline Bangladesh & 1975 & $\begin{array}{l}\text { 1972f, 1974a, 1975a, 1979a, 1980b, 1983a, } \\
\text { 1987c, 1990c }\end{array}$ \\
\hline Myanmar & 1975,1977 & 1973a, 1974a f, 1977a, 1978a, 1981a \\
\hline Sri Lanka & 1977 & $\begin{array}{l}\text { 1971a, 1972f, 1973f, 1974a f, 1977a, 1979b, } \\
\text { 1983a, 1991c }\end{array}$ \\
\hline \multicolumn{3}{|l|}{$\begin{array}{l}\text { China, P.R.: Hong } \\
\text { Kong }\end{array}$} \\
\hline India & 1976, 1991, 1995 & 1974f, 1981b, 1991a \\
\hline Indonesia & $\begin{array}{l}\text { 1978, 1983, 1986, } \\
1997\end{array}$ & 1970a, 1971a, 1972a, 1973a, 1997a \\
\hline Korea & 1980,1997 & $\begin{array}{l}\text { 1970a, 1971a, 1972a, 1973a, 1974a, 1975a, } \\
\text { 1977,80a, 1981a, 1983a, 1985a, 1997a, 1997e }\end{array}$ \\
\hline Lao People's D. R. & 1995 & 1975f, 1980a, 1989c, 1993c \\
\hline Malaysia & 1986, 1997 & \\
\hline Nepal & $\begin{array}{l}1975,1981,1984 \\
1991,1995\end{array}$ & 1975a, 1985a, 1987c, 1992c \\
\hline Pakistan & & $\begin{array}{l}\text { 1972a, 1973a, 1974a, 1980b, 1981b, 1988a c, } \\
\text { 1993a, 1994bc, 1995a, 1997bd }\end{array}$ \\
\hline Philippines & 1983, 1986, 1997 & $\begin{array}{l}\text { 1970a, 1971a, 1972a, 1973a f, 1974a, 1975a, } \\
\text { 1976bf, 1979a, 1980a, 1983a, 1984a, 1986a, } \\
\text { 1989b, 1991a, 1994b }\end{array}$ \\
\hline Singapore & 1975 & \\
\hline Thailand & 1981, 1984, 1997 & 1978a, 1981a, 1982a, 1985a \\
\hline Botswana & 1984, 1996 & \\
\hline Burundi & $\begin{array}{l}1976,1983,1986 \\
1989,1997\end{array}$ & 1970a, 1972f, 1976a, 1986c, 1991c \\
\hline Cameroon & 1982, 1984, 1994 & 1980a, 1988a, 1991a, 1994a, 1995a, 1997d \\
\hline Equatorial Guinea & 1991, 1994 & 1980a, 1985a, 1988c, 1993c \\
\hline Ethiopia & 1992 & 1981a, 1992c, 1996d \\
\hline Ghana & 1978, 1983, 1986 & $\begin{array}{l}\text { 1979a, 1983a, 1984a, 1986a, 1987bc, 1988c, } \\
\text { 1995d }\end{array}$ \\
\hline
\end{tabular}




\begin{tabular}{|c|c|c|}
\hline Guinea-Bissau & 1991, 1996 & $\begin{array}{l}\text { 1974f, 1982a, 1986a, 1987a, 1987c, 1991c, } \\
\text { 1995c, 1997d }\end{array}$ \\
\hline Kenya & $\begin{array}{l}1975,1981,1985 \\
1993,1995,1997\end{array}$ & $\begin{array}{l}\text { 1975b, 1978a, 1979a, 1980a, 1982a, 1985a, } \\
\text { 1988a c, 1989c, 1993c, 1996c }\end{array}$ \\
\hline Madagascar & $\begin{array}{l}1984,1986,1991 \\
1994\end{array}$ & $\begin{array}{l}\text { 1977a, 1980a, 1981a, 1982a, 1984a, 1985a, } \\
\text { 1986a, 1987c, 1988a, 1989c, 1996d }\end{array}$ \\
\hline Malawi & $\begin{array}{l}1982,1985,1992 \\
1994\end{array}$ & $\begin{array}{l}\text { 1979a, 1980a, 1982a, 1983b, 1988a c, 1994a, } \\
\text { 1995cd, }\end{array}$ \\
\hline Mali & 1993 & 1971a, 1982a, 1985a, 1988a c, 1992c, 1996d \\
\hline Mauritius & 1979 & 1978a, 1979a, 1980a, 1981a, 1983a \\
\hline Morocco & 1983,1990 & $\begin{array}{l}\text { 1971a, 1976f, 1980b, 1981b, 1982a, 1983a, } \\
\text { 1985a, 1988a, 1990a, 1992a }\end{array}$ \\
\hline Mozambique & 1993, 1995 & 1987c, 1990c, 1996d \\
\hline Nigeria & 1986, 1989, 1992 & 1987a, 1989a, 1991a \\
\hline Zimbabwe & $\begin{array}{l}\text { 1982, 1991, 1994, } \\
1997\end{array}$ & 1981a, 1983a, 1992bc \\
\hline Sierra Leone & 1988, 1990, 1997 & $\begin{array}{l}\text { 1976f, 1977a, 1979a, 1981b, 1984a, 1986c, } \\
\text { 1994c }\end{array}$ \\
\hline Swaziland & $\begin{array}{l}1975,1979,1982 \\
1984\end{array}$ & \\
\hline Tunisia & 1993 & 1970a, 1986a, 1988b \\
\hline Uganda & $1981,1987,1989$ & $\begin{array}{l}\text { 1970a, 1976f, 1980a, 1981a, 1982a, 1983a, } \\
\text { 1987c, 1989c, 1994c, 1997d }\end{array}$ \\
\hline Zambia & 1985,1994 & $\begin{array}{l}\text { 1972f, 1973a, 1975f, 1976a, 1978a, 1981b, } \\
\text { 1983a, 1984a, 1986a, 1995c }\end{array}$ \\
\hline Fiji & 1986 & $1974 a$ \\
\hline
\end{tabular}

1 Currency crises defined by criteria described in text, with 24-month exclusion windows imposed.

2 IMF programs:

a Stand By and Extended Stand By Agreements (SBA).

${ }^{b}$ Extended Fund Facility (EFF).

c Structural Adjustment Facility and Enhanced Structural Adjustment Facility (ESAF).

d Poverty Reduction and Growth Facility (PRGF).

e Supplemental Reserve Facility (SRF).

${ }^{f}$ Contingency and Compensatory Fund Facility (CCFF). 
Appendix Table 3

Participation Equation in short-term IMF programs - Probit Estimation Results Dependent Variable: approval of short-term IMF programs

\begin{tabular}{|c|c|}
\hline Variables & Partial derivatives \\
\hline Constant & $\begin{array}{l}-0.165^{* *} \\
(-2.21)\end{array}$ \\
\hline Post-1979 Dummy & $\begin{array}{l}0.031 \\
(0.54)\end{array}$ \\
\hline Change in current account to GDP ratio & $\begin{array}{l}-0.258 \\
(-0.94)\end{array}$ \\
\hline Change in budget surplus to real GDP ratio (t-2) & $\begin{array}{l}-0.678^{*} \\
(-1.86)\end{array}$ \\
\hline Change in budget surplus to real GDP ratio (t-1) & $\begin{array}{l}0.747^{\star *} \\
(2.22)\end{array}$ \\
\hline Inflation (t-1) & $\begin{array}{l}0.000 \\
(0.96)\end{array}$ \\
\hline Real per capita GDP growth (t-1) & $\begin{array}{l}0.001 \\
(0.79) \\
\end{array}$ \\
\hline Foreign exchange reserves to imports ratio (t-1) & $\begin{array}{c}-0.215^{\star * \star} \\
(-3.97)\end{array}$ \\
\hline Real per capita GDP - level (t-1) & $\begin{array}{c}0.000 \\
(-0.35)\end{array}$ \\
\hline Real exchange rate overvaluation (t-1) & $\begin{array}{l}0.000 \\
(0.72)\end{array}$ \\
\hline Currency crises dummy (t-1) & $\begin{array}{l}0.083^{* *} \\
(2.49)\end{array}$ \\
\hline Africa dummy & $\begin{array}{c}-0.154^{\star \star \star} \\
(-2.99)\end{array}$ \\
\hline Asia dummy & $\begin{array}{c}-0.120^{* *} \\
(-2.34)\end{array}$ \\
\hline Latin America dummy & $\begin{array}{l}0.005 \\
(0.10)\end{array}$ \\
\hline Autocracy & $\begin{array}{l}0.001 \\
(0.25) \\
\end{array}$ \\
\hline Number of observations & 862 \\
\hline Log likelihood function & -388.90 \\
\hline Significance level & 0.000 \\
\hline
\end{tabular}

\begin{tabular}{|c|c|}
\hline \multicolumn{2}{|c|}{ Goodness-of-fit (10\% cutoff) } \\
\hline \% of observations correctly called & 32 \\
\hline$\%$ of IMF programs correctly called & 96 \\
\hline \% of no program correctly called & 17 \\
\hline \multicolumn{2}{|c|}{ Goodness-of-fit (25\% cutoff) } \\
\hline$\%$ of observations correctly called & 71 \\
\hline$\%$ of IMF programs correctly called & 34 \\
\hline \% of no program correctly called & 80 \\
\hline
\end{tabular}

